\title{
Multiple Cu-ATPase genes are differentially expressed and transcriptionally regulated by Cu exposure in sea bream, Sparus aurata
}

\author{
Matteo Minghetti, Michael J. Leaver, Stephen G. George \\ Institute of Aquaculture, University of Stirling, Stirling FK94LA, Scotland, UK
}

\section{Introduction}

The variable valencies of copper $(\mathrm{Cu})$ have been exploited during evolution as a cofactor for many vital enzymes (Kim et al., 2008). On the other hand, these same redox properties enable $\mathrm{Cu}$ to promote reactions which lead to the production of reactive oxygen species (ROS) that can have damaging oxidative effects on cellular macromolecules (Halliwell and Gutteridge 1984). In addition, $\mathrm{Cu}$ may also manifest toxicity by displacing $\mathrm{Zn}$ from functionally essential protein domains (Predki and Sarkar 1992). Thus, specific proteins have evolved for intracellular $\mathrm{Cu}$ transport and delivery to avoid damaging non-specific reactions and to enable targeting to cuproproteins. These cuproproteins include $\mathrm{Cu}$-ATPases which belong to the $\mathrm{P}_{1 \mathrm{~B}}$-subfamily of $\mathrm{P}$-type ATPases present in all eukaryotic phyla (Lutsenko et al., 2007b). Cu-ATPases transfer Cu from the cytosolic carrier, ATOX1 (Hamza et al., 2003), to secretory vesicles (Petris et al., 2000). The essentiality of $\mathrm{Cu}$-ATPases in normal development and pigmentation was reported in Drosophila (Norgate et al., 2006), whilst in the zebrafish (Danio rerio) ATP7A was shown by mutagenetic analysis and genetic complementation to be essential for notochord formation and pigmentation (Mendelsohn et al., 2006).

Two isoforms of Cu-ATPase (ATP7A and ATP7B) with differing functional roles have been identified in mammals, primarily by investigation of two human genetic disorders, Menkes syndrome and Wilson's disease. Menkes syndrome is caused by mutations of the gene encoding ATP7A (also known as Menkes protein) and is characterized by overall $\mathrm{Cu}$ deficiency and accumulation of $\mathrm{Cu}$ in intestinal enterocytes and the kidney. Wilson's disease is caused by mutations in ATP7B (also known as Wilsons protein) and is associated with hepatic Cu overload (Mercer 2001). Cu-ATPases have a dual role; they deliver $\mathrm{Cu}$ to cuproenzymes within the secretory pathway (e.g. ATP7A delivers $\mathrm{Cu}$ to lysyl oxidase and ATP7B delivers $\mathrm{Cu}$ to ceruloplasmin) and they are also responsible for excretion of excess intracellular $\mathrm{Cu}$ (Lutsenko et al., 2008). Body $\mathrm{Cu}$ homeostasis is achieved manly by regulating intestinal absorption (through ATP7A) and biliary excretion by the liver (through ATP7B). Mutated Cu-ATPase phenotypes show that the two mammalian isoforms have distinct homeostatic roles and operate in different tissues, although in some tissues, such as the brain and kidney, there is evidence of functional redundancy (Linz and Lutsenko 2007). 
In fish much less is known, but there is evidence that, as in mammals, whilst intestinal absorption is proportional to the concentration of $\mathrm{Cu}$ in the diet, regulation is achieved by basolateral membrane extrusion in an ATP-dependent manner and by a $\mathrm{Cu}$ /anion symporter (Clearwater et al., 2000; Handy et al., 2000). In the gill the existence of a functional Cu-ATPase (ATP7A-like protein), has been suggested by the inhibition of $\mathrm{Cu}$ transport by vanadate, a specific inhibitor of P-type ATPases (Campbell et al., 1999). In addition, Bury et al., (1999) identified an ATP-dependent silver transporter at the basolateral membrane. Thus, since silver is known to mimic $\mathrm{Cu}$, this finding would support a hypothesis of branchial basolateral $\mathrm{Cu}$ transport mediated by a fish homologue of the mammalian ATP7A. Recently, Craig et al., (2009) have shown that ATP7A is expressed in the gill, gut and liver of zebrafish and that waterborne $\mathrm{Cu}$ increased its intestinal and hepatic mRNA levels. Although these studies provide evidence for a role of ATP7A in Cu transport in fish, there have been no reports of the existence or the expression of an ATP7B homologue in fish. Following our previous study where we demonstrated that a high affinity $\mathrm{Cu}$ transporter (CTR1) was mainly expressed in the intestine of the gilthead sea bream (Sparus aurata) and that its mRNA levels were differentially regulated by dietary or waterborne $\mathrm{Cu}$ (Minghetti et al., 2008), in this study we have investigated the expression of the intracellular $\mathrm{Cu}$ chaperone, ATOX1 and $\mathrm{Cu}$ ATPases homologues in this species.

\section{Material and methods}

\subsection{Animals treatments and RNA extraction}

The samples analyzed in this study and their processing including RNA extraction and cDNA synthesis are described in Minghetti et al. (2008). Briefly, juvenile gilthead sea bream (Sparus aurata), average 40g mass, were obtained from farm stock (Valle Ca' Zuliani, Rovigo, Italy). Experimental tanks were supplied with seawater pumped ashore from the Adriatic Sea. Water temperature was $19.0 \pm 0.5^{\circ} \mathrm{C}$ and a salinity of $33.6 \pm 2.6 \%$. The trial was performed at the Marine Research Centre of Cesenatico, Bologna University, Italy. Fish were fed two experimental diets containing $7.7 \pm 0.3 \mathrm{mg} \mathrm{Kg}^{-1} \mathrm{Cu}$ (low $\mathrm{Cu}$ diet) or containing $130 \mathrm{mg} \mathrm{Kg}^{-1} \mathrm{Cu}$ (high Cu diet), alternatively fish were fed the low $\mathrm{Cu}$ diet but were exposed to $\mathrm{Cu}$ dissolved in marine water at a concentration of $0.3 \mathrm{mg} \mathrm{L}^{-1} \mathrm{Cu}$. There were no mortalities in the tanks. After a period of 15 days (day 15) and 30 days (day 30) five fish chosen randomly from each tank were removed, killed by a blow to the head and tissues immediately sampled for RNA extraction and metal analysis. Total RNA was prepared using TriReagent (Sigma, UK) according to the manufacturer's instructions and RNA quality was checked by spectrophotometry and agarose gel electrophoresis. 


\subsection{Synthesis of Sea bream ATP7A, ATP7B and ATOX1 cDNAs}

Degenerate primers were designed by selecting conserved areas from alignments of protein sequences derived from ATP7 and ATP7-like DNA sequences of human (Homo sapiens) (NM_000052), chick (Gallus gallus) (XM_420307), zebrafish (Danio rerio) (Ensembl transcript ID: ENSDART00000054977) and pufferfish (Tetraodon negroviridis) (Ensembl transcript ID: GSTENT00017010001) ATP7A; human (NM_000053), zebrafish (Ensembl transcript ID: ENSDART00000030246), pufferfish (Ensembl transcript ID: GSTENG00020077001) and stickleback (Gasterosteus aculeatus) (Ensembl transcript ID: ENSGACG00000014945) ATP7B; and human (NM_004045), rat (Rattus norvegicus) (AF177671), chick (XM_001233562) and puffer fish (Ensemble transcript ID: GSTENT00024266001) ATOX1 (Table 1).

Partial ATP7A, ATP7B and ATOX1 cDNAs were generated by PCR using $0.5 \mu \mathrm{M}$ of primers (ATP7A: 1, Atp7AF2, Atp7AR5 and 2, Atp7AF7, Atp7AR9; ATP7B: Atp7BF1, Atp7B-R5; ATOX1: Atox1F2, Atox1R3), one eighth $(2.5 \mu \mathrm{l})$ of the cDNA (from sea bream intestine) synthesis reaction, one unit of Taq polymerase with supplied buffer IV (ABgene, UK) and $1 \mathrm{mM} \mathrm{MgCl}_{2}$ in a final volume of $25 \mu$ l. The thermocycling conditions were: ATP7A 1: $94^{\circ} \mathrm{C}$ for $3 \mathrm{~min}$ followed by 30 cycles $94^{\circ} \mathrm{C} 30 \mathrm{sec}-52^{\circ} \mathrm{C} 30 \mathrm{sec}-72^{\circ} \mathrm{C} 2 \min$ followed by $72^{\circ} \mathrm{C}$ for $7 \mathrm{~min}$. ATP7A 2: $94^{\circ} \mathrm{C}$ for 3 min followed by 30 cycles $94^{\circ} \mathrm{C} 30 \mathrm{sec}-56^{\circ} \mathrm{C} 30 \mathrm{sec}-72^{\circ} \mathrm{C} 1.5 \mathrm{~min}$ followed by $72^{\circ} \mathrm{C}$ for $7 \mathrm{~min}$. ATP7B: 1 cycle at $95^{\circ} \mathrm{C}$ for $2 \mathrm{~min}, 30$ cycles $95^{\circ} \mathrm{C} 30 \mathrm{sec}, 58^{\circ} \mathrm{C} 30 \mathrm{sec}, 72^{\circ} \mathrm{C} 3 \mathrm{~min}$ followed by $72^{\circ} \mathrm{C}$ for $7 \mathrm{~min}$. ATOX $1: 94^{\circ} \mathrm{C}$ for 3 min followed by 30 cycles $94^{\circ} \mathrm{C} 30 \mathrm{sec}-56^{\circ} \mathrm{C} 30 \mathrm{sec}-72^{\circ} \mathrm{C} 30$ sec followed by $72^{\circ} \mathrm{C}$ for $7 \mathrm{~min}$. The PCR products obtained, which were 1500 and 1200 base pairs (bp) for ATP7A-1 and ATP7A-2 respectively, $2270 \mathrm{bp}$ for ATP7B and $200 \mathrm{bp}$ for ATOX1 were cloned into a 2.1 plasmid (Topo TA, Invitrogen, Paisley, UK) and sequenced (CEQ-8800 Beckman Coulter Inc., Fullerton, USA). The probable identities of the cloned PCR products were predicted using BLAST (http://www.ncbi.nlm.nih.gov/BLAST/). RACE-PCR (Rapid Amplification of cDNA Ends) was performed using the SMARTTM RACE kit (Clontech, USA). RACE cDNA was generated as described in the kit manual from $1 \mu \mathrm{g}$ of intestinal sea bream total RNA. ${ }^{\prime}$ ' and 3' RACE amplicons were generated by two rounds of PCR using gene specific primers designed from the sequence of the initial cDNAs for ATP7A (5'RACE: 5'Atp7A-R1, 5'Atp7A-R2 and 3'RACE: 3'Atp7A-F1), for ATP7B (5'RACE: 5'Atp7B-R1, 5'Atp7B-R2 and 3'RACE: 3'Atp7B-F2, 3'Atp7B-F1) and for ATOX1 (5'RACE: 5'Atox1-R1, 5'Atox1-R2 and 3'RACE: 3'Atox1-F1, 3'Atox1-F2). The final full-length PCR products were obtained by two round of PCR using primers Atp7AFull-F1, Atp7AFull-R1 and Atp7AFull-F2, Atp7AFull-R2 for ATP7A; Atp7BFull-F1, Atp7BFull-R1 and Atp7BFull-F2, Atp7BFull-R2 for ATP7B or one round of PCR using primers Atox1Full- F, Atox1Full-R for ATOX1, designed from the 5' and 3' RACE products. The annealing temperature for all primers was $60^{\circ} \mathrm{C}$ and the extension time was $1 \mathrm{~min} / \mathrm{Kb}$ of predicted 
PCR product, and 3 min were applied for unpredictable RACE PCR products. All primers are listed in Table 1 and were designed using PrimerSelect Ver. 6.1 program (DNASTAR, www.dnastar.com). Sequencing was performed using a Beckman 8800 autosequencer. Lasergene SEQman software (DNASTAR) was used to edit and assemble DNA sequences. Since Cu-ATPases sequence annotation was incomplete in other fish species with a sequenced genome, and in order to predict the full length polypeptide sequences, the sea bream cDNA sequences coding for $\mathrm{Cu}$ ATPase genes were used to search puffer fish (Tetraodon nigroviridis), medaka (Oryzias latipes), stickleback (Gasterosteus aculeatus) and zebrafish genomes (www.Ensembl.org) using TBlastX. Regions of puffer fish, medaka, stickleback and zebrafish chromosomal DNA sequences containing homologous sequences were then processed with GeneWise2 (www.ebi.ac.uk) using the sea bream sequence as a key to generate predicted polypeptide sequences. ClustalW (Thompson et al., 2000) was used to generate multiple alignments of deduced protein sequences. To deduce and bootstrap phylogenetic trees using the neighbour joining method (Saitou and Nei 1987), MEGA version 4 was used (Tamura et al., 2007).

\subsection{Quantitative RT-PCR}

Complementary DNA synthesis reactions for qRT-PCR contained Superscript RT (Clontech), $3 \mu \mathrm{g}$ of total RNA and $500 \mathrm{ng}$ oligo- dT primer in a volume of $20 \mu \mathrm{L}$ and were incubated at $42{ }^{\circ} \mathrm{C}$ for 1.5 $\mathrm{h}$ followed by $70{ }^{\circ} \mathrm{C}$ for $15 \mathrm{~min}$. Oligonucleotide primers for target genes, ATP7A (GQ200817), qAtp7A-F and qAtp7A-R, ATP7B (GQ200818), qAtp7B-F and qAtp7B-R, ATOX1 (AJ966735), qAtox1-F and qAtox1-R, and reference genes, $\beta$--actin (X89920), qActinF and qActinR, GAPDH (DQ641630) qGapdhF and qGapdhR and EF1 $\alpha$ (AF184170) qEF1 $\alpha$ F and qEF1 $\alpha$ R (Table 1) were used at $0.3 \mu \mathrm{M}$ with one fortieth of the cDNA synthesis reaction (5 $\mu \mathrm{l}$ of a 1:10 dilution) and $10 \mu \mathrm{l}$ of SYBR-green qRT-PCR mix (ABgene, UK) in a total volume of $20 \mu 1$. Reactions were run in a Techne Quantica thermocycler at anneal temperatures of $56{ }^{\circ} \mathrm{C}$ for $\beta$-actin, ATOX1 and ATP7A and $60{ }^{\circ} \mathrm{C}$ for GAPDH and EF1 $\alpha$ and $62^{\circ} \mathrm{C}$ for ATP7B a to give a PCR product of 171, 130, 175, 250, 174 and 157 bp respectively. Each qRT-PCR product was than sequenced to confirm its identity and was found to be $100 \%$ identical to its predicted sequence. Quantification was achieved by a parallel set of reactions containing standards consisting of serial dilution of spectrophotometrically determined, linearised plasmid containing salmon ATP7A, ATP7B, ATOX1, $\beta$-actin, GAPDH and EF1 $\alpha$ cDNA sequences. Normalisation of copy number across biological samples was achieved by using a normalization factor (NF), calculated tissue by tissue, based on the geometric mean expression of three reference genes ( $\beta$-actin, GAPDH or EF1 $\alpha$ ) determined using geNorm software (Vandesompele et al., 2002). GeNorm was used to select the 
two most stable genes for a particular tissue, which were then used to normalize target gene expression level. However, all reference gene expression levels varied widely between tissues and therefore the comparison of expression levels of target genes in different tissues was achieved by normalising the target gene copy number to total input RNA.

\subsection{Tissue copper, metallothionein and glutathione reductase mRNA levels}

The measurement of total copper and metallothionein (MT) and glutathione reductase (GR) mRNA levels in the tissues of the fish from these experiments have been described previously (Minghetti et al., 2008).

\subsection{Statistical analysis}

Statistical analysis was performed using the Minitab v.15.1 statistical software package (Minitab Inc., USA). Data was first assessed for normality with the Kolmogorov-Smirnov test and for homogeneity of variances by Bartlett's test and examination of residual plots. Where necessary sample data was transformed to improve normality. Sample data was analysed by full factorial two way analysis of variance (ANOVA). Post hoc multiple comparisons were applied using Tukey's test (Zar 1999). A significance of $p<0.05$ was applied to all statistical tests performed. All data are presented as mean \pm SD.

Table 1. Primers used for cDNA isolation and qRT-PCR.

\begin{tabular}{lllll}
\hline ID & Sequence 5 $\rightarrow 3^{\prime}$ & length & Tm & $G C \%$ \\
\hline Atox1F2 & gcacgaatttgaggtggccatgac & 24 & 64.4 & 54.2 \\
Atox1R3 & cgtcacttggtgccgatgtactt & 23 & 62.4 & 52.2 \\
5'Atox1-R1 & gacctcctttccacatttctgcagcg & 26 & 66.4 & 53.8 \\
5'Atox1-R2 & gtcacagctcctgaacaaccctcacac & 27 & 68 & 55.6 \\
3'Atox1-F1 & gtgtgagggttgttcaggagctgtgac & 27 & 68 & 55.6 \\
3'Atox1-F2 & cgctgcagaaatgtggaaaggaggtc & 26 & 66.4 & 53.8 \\
Atox1Full-F & ttcgagtcagccggaggtgaaa & 22 & 62.1 & 54.5 \\
Atox1Full-R & catctaagaggggaggggtgtca & 23 & 64.2 & 56.5 \\
Atp7AF2 & gargacatgggntttgatgc & 20 & & \\
Atp7AF7 & cgmttygccttccargcctc & 20 & & \\
Atp7AR5 & gctggatrggmgccttga & 19 & & \\
Atp7AR9 & cccatccarggctgcarmacca & 22 & & \\
5'Atp7A-R1 & catagtttccatgacggaggcggtgaagc & 30 & 69.5 & 53.3 \\
5'Atp7A-R2 & tccgatctggatgtagcatttggagtgc & 28 & 66.6 & 50 \\
3'Atp7A-F1 & agaagcagcagatgtggtgttgat & 24 & 61 & 45.8 \\
Atp7AFull-F1 & gacgtgcctgcttcgctgcttgtaa & 25 & 66.3 & 56 \\
Atp7AFull-F2 & aagacgaagcaatcatgacacagaaagt & 28 & 62.2 & 39.3 \\
Atp7AFull-R1 & cagaggatcacagggtaggccaaagagt & 28 & 68 & 53.6 \\
Atp7AFull-R2 & agttgttgctggaccacgtgaaccttac & 28 & 66.6 & 50 \\
Atp7B-F1 & ttcaartgygtcaacagyctg & 21 & & \\
Atp7B-R5 & cgacgaccgcaggcttctcatttg & 24 & 66.1 & 58.3 \\
5'Atp7B-R1 & aggaagaaggccaggttgaggag & 23 & 64.2 & 56.5 \\
5'Atp7B-R2 & accacctgctcctcgctgatgat & 23 & 64.2 & 56.5 \\
3'Atp7B-F1 & gtsctgatccggaacgayytgct & 23 & & \\
3'Atp7B-F2 & gcatcgagctstcyaaraagac & 22 & & \\
& & & &
\end{tabular}




\begin{tabular}{lllll} 
Atp7BFull-F1 & ataagaggccagccggtgtgagag & 24 & 66.1 & 58.3 \\
Atp7BFull-F2 & gtagcttcactttgggttgttagcag & 26 & 63.2 & 46.2 \\
Atp7BFull-R1 & agcatgttttctcctaagtcg & 21 & 55.9 & 42.9 \\
Atp7BFull-R2 & ttccegccaaagtaagagc & 19 & 56.7 & 52.6 \\
qAtp7A-F & gatgttgagttggtgcagaggg & 22 & 62.1 & 54.5 \\
qAtp7A-R & ggttaatggagcctgcgatc & 20 & 59.4 & 55 \\
qAtp7B-F & cgctggcctcgtgcttcaacc & 21 & 65.7 & 66.7 \\
qAtp7B-R & cgacgaccgcaggcttctcattt & 23 & 64.2 & 56.5 \\
qAtox1-F & gtgtgagggttgttcaggagc & 21 & 61.8 & 57.1 \\
qAtox1-R & gagaacttcacgtcttgtcg & 22 & 60.3 & 50 \\
qActinF & gaccaactgggatgacatgg & 20 & 59.4 & 55 \\
qActinR & gcatacagggacagcacagc & 20 & 61.4 & 60 \\
qGapdhF & tgcccagtacgttgttgagtccac & 24 & 64.4 & 54.2 \\
qGapdhR & cagaccctcaatgatgccgaagtt & 24 & 62.7 & 50 \\
qEF1 $\alpha F$ & catggttgtggagcccttct & 20 & 59.4 & 55 \\
qEF1 $\alpha R$ & tcctgcacgaccattcattc & 21 & 57.9 & 47.6 \\
\hline
\end{tabular}

$\mathrm{Tm}=69.3+0.41 *$ GC\% $-(650 /$ length $)$. Tm temperature and GC $\%$ was not calculated for degenerate primers.

\section{Results}

\subsection{Sea bream Cu-ATPase and ATOX1 cDNAs}

Copper ATPases and their specific $\mathrm{Cu}$ chaperone ATOX1 have not been previously reported in sea bream, it was therefore important to identify their mRNA (cDNA) sequence enabling the measurement of their tissue expression profile in normal and under excess $\mathrm{Cu}$ conditions. The full length cDNA of ATP7A obtained from sea bream (saATP7A) was 5474 bp which contained an open reading frame of $4566 \mathrm{bp}$ (1522 amino acids) and 5' end 3' untranslated regions of $294 \mathrm{bp}$ and 614 bp respectively (GenBank accession number GQ200817). The deduced saATP7A protein sequence displayed $63 \%$ identity with human ATP7A and $74 \%$ with zebrafish ATP7A sequences. The full length cDNA of ATP7B from sea bream (saATP7B) of 4294 bp contained an open reading frame of $3981 \mathrm{bp}$ (1327 amino acids) and 5' end 3' untranslated regions of $61 \mathrm{bp}$ and $252 \mathrm{bp}$ respectively (GenBank accession number GQ200818). The deduced protein sequence of saATP7B displayed $59 \%$ identity with the human ATP7B sequence. Sea bream ATOX1 (saATOX1) full length cDNA was $1374 \mathrm{bp}$, consisting of an open reading frame of $204 \mathrm{bp}$ (68 amino acids) and 5' end 3' untranslated regions of 90 bp and 1080 bp respectively (GenBank accession number AJ966735).

Alignments of the deduced amino acid sequence of $\mathrm{Cu}$-ATPases (ATP7A and ATP7B) proteins derived from genome sequences of other fish species, bird and human and also from Cu-ATPases from insects, worms and yeast show very strong sequence conservation (Figure 1). The proteins' features which characterize mammalian $\mathrm{Cu}$-ATPases such as the 6 MBDs (ATP7A), 8 transmembrane domains (TMDs) including residues in the transmembrane domains believed from modelling and mutational analysis to be involved in $\mathrm{Cu}$-binding, notably the $\mathrm{C}^{1000} \mathrm{PC}^{1002}$ motif in 
TMD6, YN in TMD7 and the MxxS motif in TMD8 were also totally conserved in fish ATP7A (supplementary Figure 1) and with the exception of the $\mathrm{D}^{1497} \mathrm{TAL}^{1500}$ all the other functionally important motifs (Lutsenko et al., 2007a) were conserved in saATP7A. On the other hand, saATP7B and other fish ATP7Bs including Pufferfish, Fugu, Medaka and Stickleback ATP7Bs possessed only 4 of the 6 metal binding domains (MBDs) present in higher vertebrates, while Zebrafish ATP7B possessed 5 MBDs. The apical membrane targeting domain at the N-terminus of ATP7B (Braiterman et al., 2009) was conserved in all vertebrate sequences analyzed (Figure 2A). Moreover, the di-leucine golgi retention motif (LL) at the C-terminus was conserved in all $\mathrm{Cu}$ ATPases analysed excluding the sea squirt ATP7 and yeast Ccc2 (Figure 2B and supplementary figure 2).

Phylogenetic analysis of $\mathrm{Cu}$-ATPases showed that sea bream and all other vertebrate ATP7A and ATP7B robustly segregated in two separate branches. The fish sequences clustered together in each branch with sea bream showing greatest similarity to the pufferfish sequence (Figure 3).

Sea bream ATOX1 (GeneBank accession number AJ966735) showed $60 \%$ identity with the human sequence. Alignment of the deduced amino acid sequence of saATOX1 with ATOX1 proteins from other fish species, frog, chick, human, insects and yeast showed strong sequence conservation. The MBD (MxCxxC) (Hung et al., 1998; Wernimont et al., 2000) and the recently identified nuclear localization signal (NLS) (xKxGK) (Itoh et al., 2008) are highly conserved from yeast to humans. Moreover, the $\mathrm{K}^{65}$ which was demonstrated to be essential for $\mathrm{Cu}$ transport by mutational analysis is also conserved in all sequences (Portnoy et al., 2001) (fig.ure 4A). Phylogenetic analysis of available ATOX1 sequences indicated that the fish sequences were monophyletic and that the sea bream ATOX1 was most closely related to the pufferfish protein (figure 4B).

To verify whether fish species contain multiple genes for $\mathrm{Cu}$ transporters for which only single mammalian examples exist, the sea bream cDNA sequence was used to search for similar sequences in the zebrafish, pufferfish, medaka and stickleback genomes. In each species a single ATP7A, ATP7B and ATOX1 gene was identified. 


\section{Cu ATPases structural features}

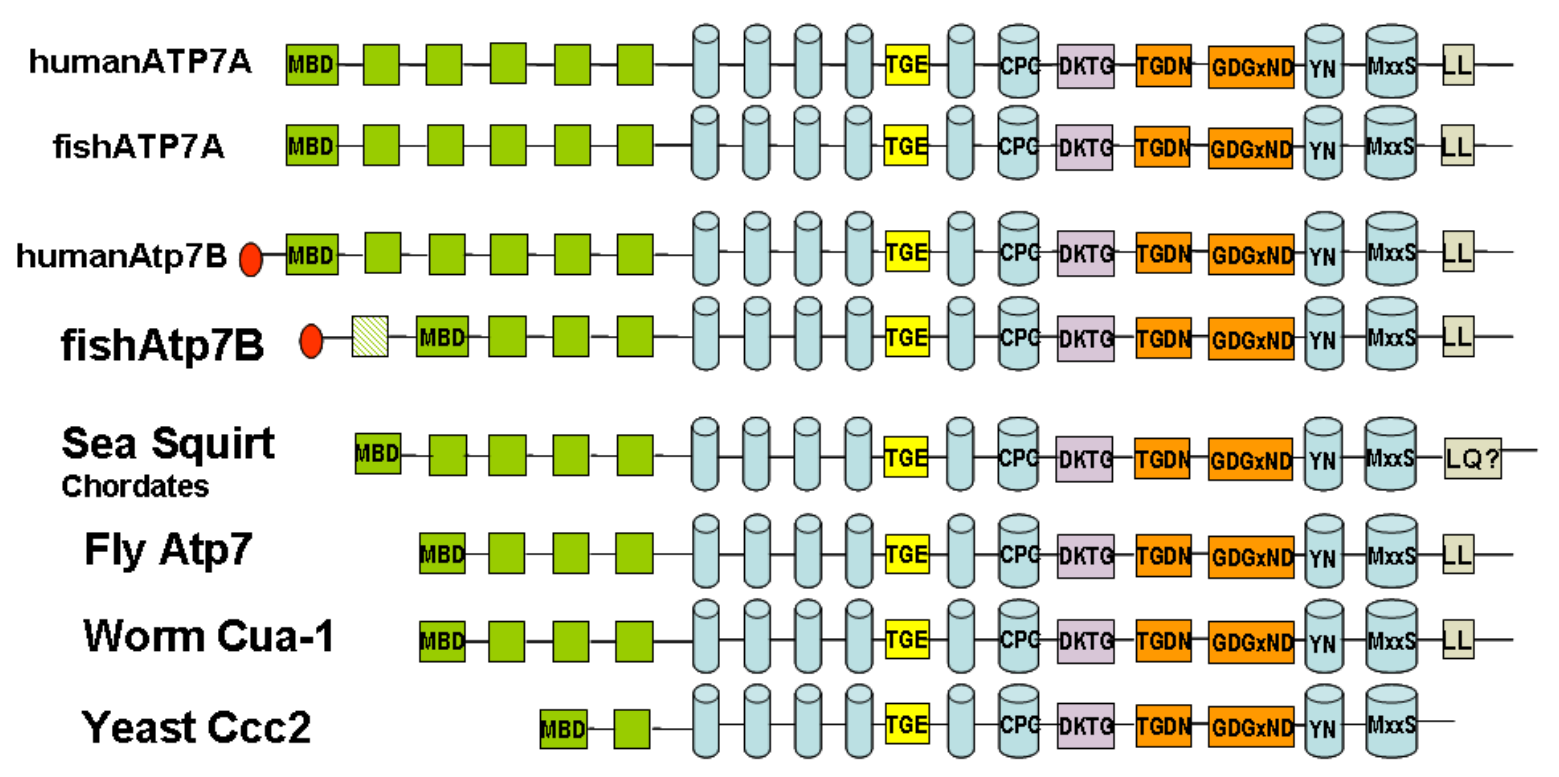

Apical targeting and Golgi retention signals

Figure 1: Cu-ATPases structural features. Structural conserved motifs are indicated. The motifs characterizing P-Type ATPases are the motif required for phosphatase activity in yellow, phosphorylation domain in purple, ATP-binding site in orange. The residues predicted to be involved in Cu coordination within the membrane in TMD6, 7 and 8 are indicated (Lutsenko et al., 2007a). Fish ATP7B showed four (sea bream, fugu, medaka and stickleback) or five (zebrafish) MBDs which are shown in green.

\section{A}

Human

Chicken

Frog

Sea bream

Pufferfish

Zebrafish

\section{B}

Human-ATP7A

Seabream-ATP7A

Human-ATP7B

Chicken-ATP7B

Seabream-ATP7B

Ciona-Atp 7

Drosophila-ATP7

Nematode-Cua-1

Yeast-Ccc2
Chicken-ATP7A
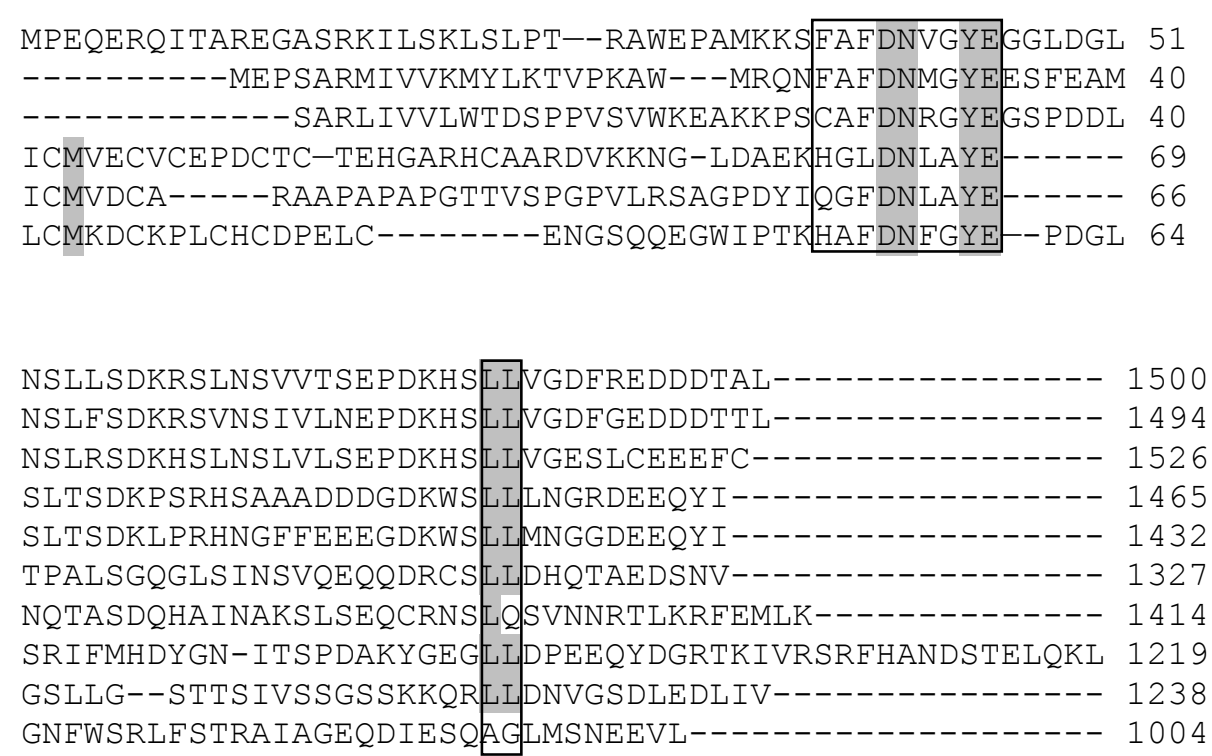

Figure 2 A: ATP7B N-terminus showing conservation of the apical targeting and Golgi retention signals (Braiterman et al., 2009). B: Cu-ATPases C-terminus showing conservation of the LL-motif involved in trafficking signals. Residues identical in all proteins are shaded. Structural motifs are boxed. Full sequence alignments are reported in supplemented figure 1 and 2. 


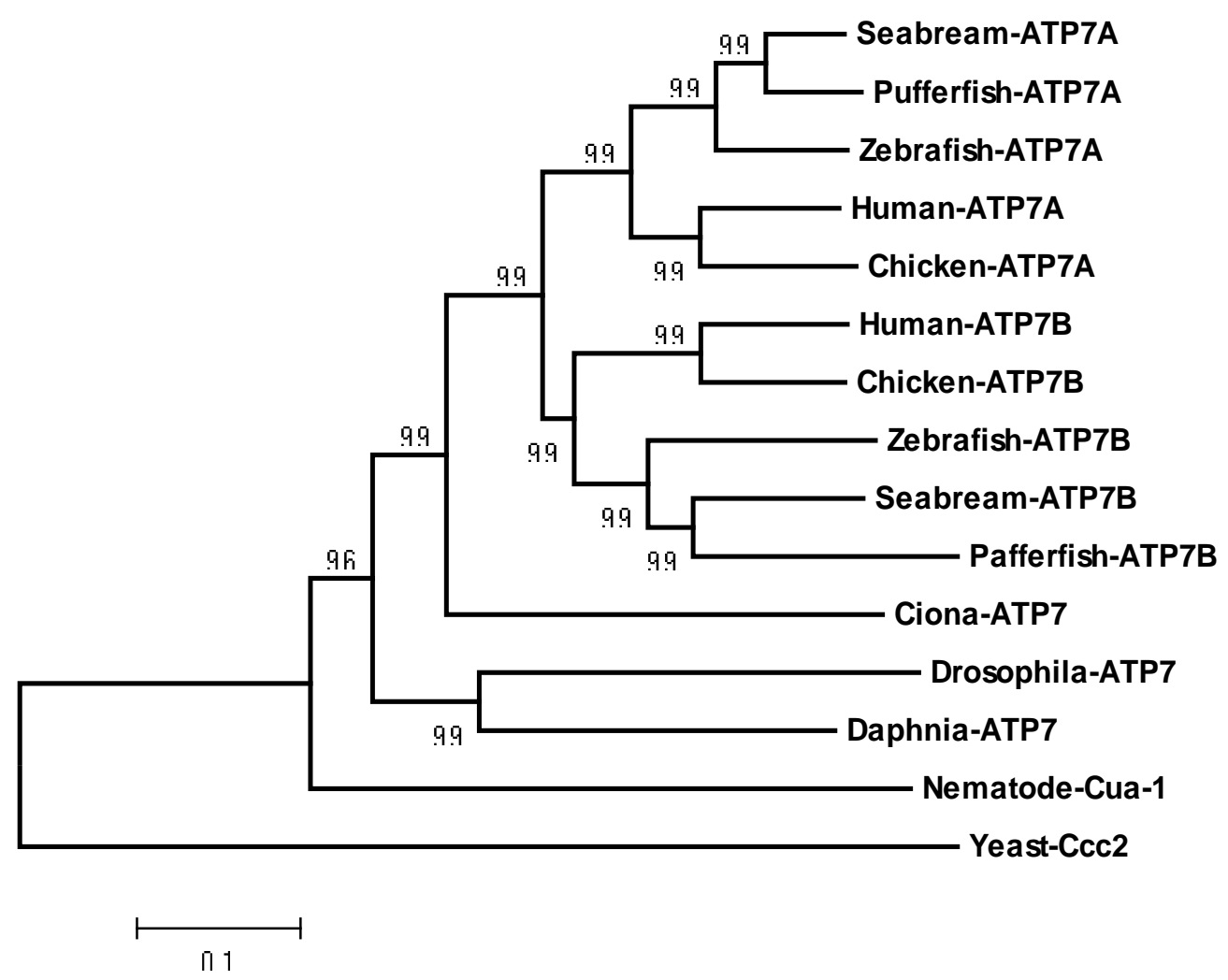

Figure 3: Cu-ATPases phylogeny tree. Human ATP7A (NM_000052) and ATP7B (NM_000053) chick (Gallus gallus) ATP7A (XM_420307) and ATP7B (XM_417073), zebrafish ATP7A (Danio rerio, Ensemble Chr14 ENSDARG00000003699, NP_001036185) and ATP7B (Ensemble Chr6 ID: ENSDART00000030246) pufferfish ATP7A (Tetraodon negroviridis) (Ensemble Chr1 GSTENG00017010001) and ATP7B (Ensemble Chr3 GSTENG00020077001), sea bream (Sparus aurata) ATP7A (GQ200817) and ATP7B (GQ200818), sea squirt (Ciona intestinalis) (Ensembl-Chr14q ENSCING00000007245), fruit fly (Drosophila melanogaster) ATP7 (AE014298), Daphnia (Daphnia pulex) ATP7 (Daphnia pulex v1.0, PASA_GEN_0100302), nematode (Caenorhabditis elegans) Cua-1 (NM_067377), and yeast Ccc2 (Saccharomyces cerevisiae) (L35270), were used to generate the phylogenetic tree using ClustalW. Numbers (bootstrap values) represent the percentage of times the associated branch topology was returned after 1000 iterations of tree generation.

\section{A}

\section{Seabream \\ Pufferfish \\ Human \\ Chicken \\ Frog \\ FruitFly \\ Yeast}

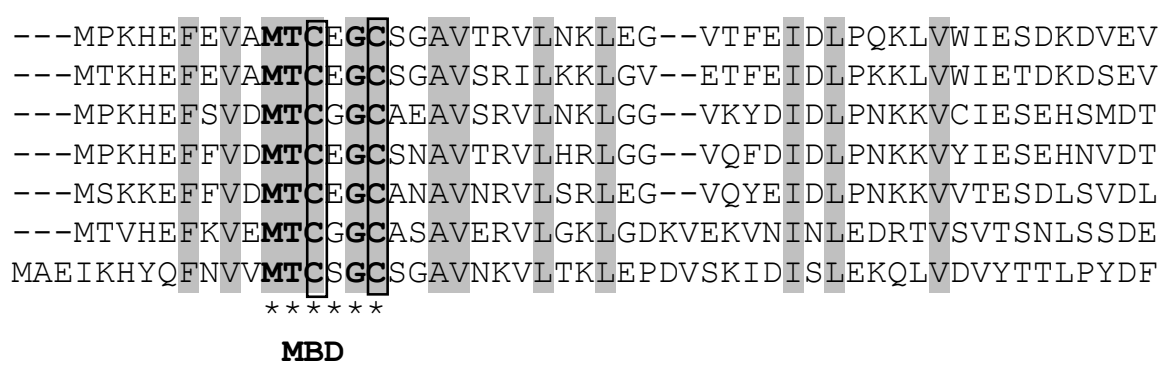

LMQTLQKCGREVKYNGTK- 68

LMEALKKSGKEVKYNGTK- 68

LLATLKKTGKTVSYLGLE- 68

LLETLKKTGKSASYLGEK- 68

LLETLKKTGKEAKYLGCK- 68

LMEQLRKTGKSTTYVGVKK 71

ILEKIKKTGKEVR-SGKQL 73

NLS 


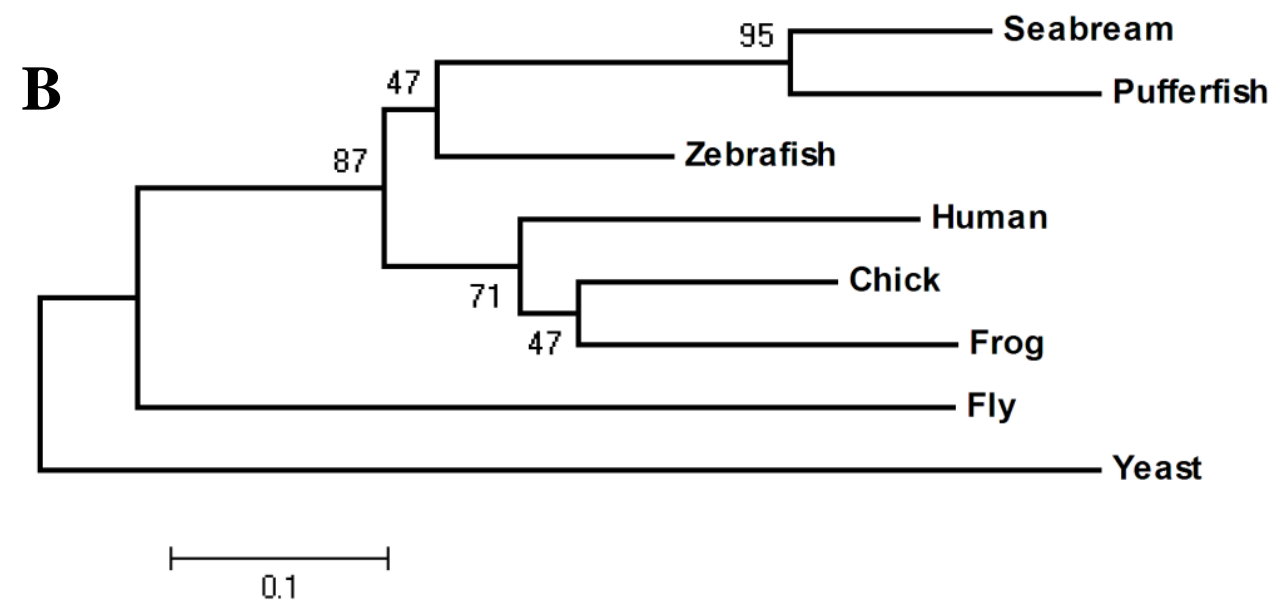

Figure 4. ATOX1 structural features. A: ATOX1 sequence alignment. Residues identical in all proteins are shaded. The metal binding domain (MBD) is indicated. The residues shown to be required for the activity of yeast ATX1 (Banci et al., 2007a) are boxed. B: Atox1 phylogenetic tree. Human (NM 004045), chick (XM 001233562), frog (Xenopus tropicalis, NM 001045773), fruit fly (NM_168932), yeast (L35270), zebrafish (XM 679218), puffer fish (Ensemble-Chr1 scaf14742) and the sea bream ATOX1 (AJ966735) were used to generate the phylogenetic tree using ClustalW. Numbers (bootstrap values) represent the percentage of times the associated branch topology was returned after 1000 iterations of tree generation.

\subsection{Tissue distribution of Cu-ATPases and ATOXI}

Expression profiles of $\mathrm{Cu}-\mathrm{ATPases}$ and ATOX1 mRNAs are reported in Figure 5. SaATP7A mRNA was expressed at lower levels in all tissues, compared to ATP7B and ATOX1. For ATP7A, the highest level of expression was found in the brain, whilst kidney, gill, intestine, heart, white and red muscle showed similar levels which were between 2.3 -(kidney) and 4.5- (white muscle) fold lower then brain levels. ATP7A expression in the liver was low with mRNA levels 23.8- fold lower that in the brain and between 10- and 5-fold lower than kidney and white muscle respectively. Sea bream ATP7B mRNA expression was highest in the intestine and was between 4 -and 200-fold higher than the liver and the heart respectively. Following the intestine, the liver showed the second highest expression, with ATP7B mRNA expression levels between 14- and 54-fold higher than white muscle and heart respectively. ATP7B in the kidney and brain was expressed at similar levels, about one third lower than the liver and between 19- and 5- fold higher than the heart and white muscle respectively.

Sea bream ATOX1 mRNA was expressed at similar levels in the kidney and brain, levels which were between 3- to 13.4- fold higher then those in the gill, intestine, liver, white and red muscle. Moreover ATOX1 expression was 1.8-fold higher in the kidney than in the heart. 

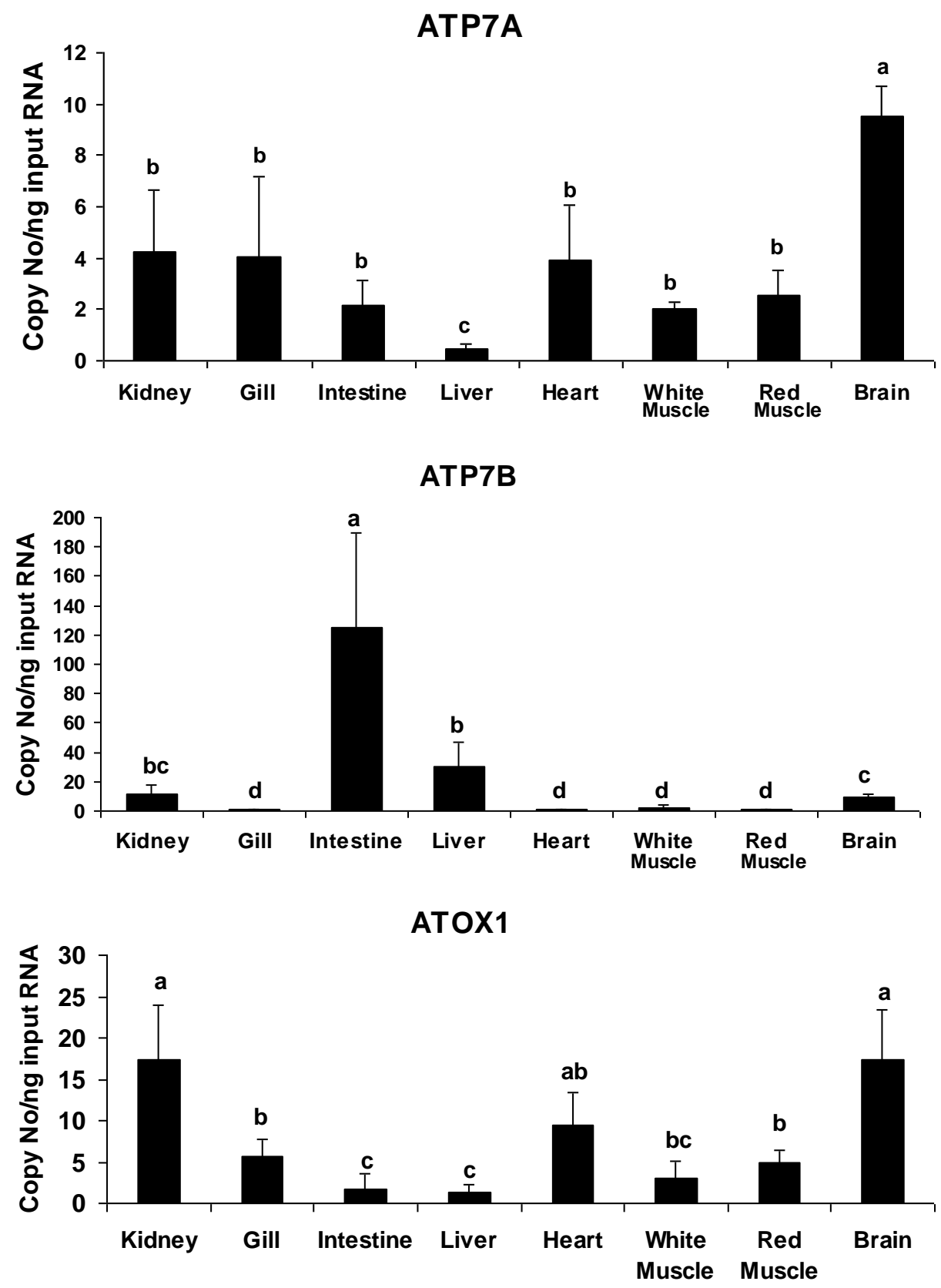

Figure 5. ATP7A, ATP7B and Atox1 tissue expression profile. Messenger RNA levels were determined by QPCR of cDNA synthesized from equal amounts of total RNA from each tissue. Values are means \pm S.D. $\mathrm{n}=5$. Bars bearing different lettering are significantly different $(\mathrm{P}<0.05$; ANOVA, Tukeys test).

\subsection{Effect of excess dietary and waterborne copper on ATP7A, ATP7B and ATOX1 expression}

The effects of excess dietary (130 versus $7.7 \mathrm{mg} \mathrm{Kg}^{-1} \mathrm{Cu}$ ) or waterborne $\left(0.3\right.$ versus < $0.005 \mathrm{mg} \mathrm{L}^{-1}$ $\mathrm{Cu}) \mathrm{Cu}$ exposure on tissue $\mathrm{Cu}$ concentrations and expression of $\mathrm{Cu}$-transporter gene expression after 15 and 30 days exposure in sea bream tissues are shown in Figure 6. Elevated $\mathrm{Cu}$ in the diet resulted in a reduction of intestinal (up to 8.5-fold), renal (up to 23 -fold), branchial (up to 5-fold) and hepatic (up to 4.6 -fold) ATP7A at both 15 and $30 \mathrm{~d}$ of treatment. Waterborne $\mathrm{Cu}$ exposure in fish fed the low $\mathrm{Cu}$ diet $\left(7.7 \mathrm{mg} \mathrm{Kg}^{-1} \mathrm{Cu}\right.$ ) resulted in an increase of intestinal (up to 43.5 -fold) and 
hepatic (up to 4 -fold) ATP7A compared to unexposed fish. In contrast after waterborne $\mathrm{Cu}$ exposure, ATP7A expression decreased in the gill (at $15 \mathrm{~d}$; 5- fold) and kidney (up to 3.4 -fold). ATP7B mRNA expression was affected by $\mathrm{Cu}$ exposure only in the liver. In fish fed the high $\mathrm{Cu}$ diet hepatic ATP7B was 3.7 -fold higher at $15 \mathrm{~d}$ than in low $\mathrm{Cu}$ diet fed fish, although there were no differences after 30 days. Waterborne $\mathrm{Cu}$ in fish fed the low $\mathrm{Cu}$ diet resulted in an increase of hepatic ATP7B mRNA at $15 \mathrm{~d}$ and $30 \mathrm{~d}$ (up to 5- fold).

ATOX1 expression was reduced by dietary $\mathrm{Cu}$ in the liver at $15 \mathrm{~d}$ (2.2-fold). Conversely, waterborne $\mathrm{Cu}$ reduced ATOX1 expression in the gill ( $30 \mathrm{~d}$; 2.4 fold), kidney ( $30 \mathrm{~d}$; 2.6 - fold) and liver (up to 3- fold). Moreover, fish fed the low $\mathrm{Cu}$ diet showed a decrease in ATOX1 mRNA level in the intestine at $30 \mathrm{~d}$.

\subsection{Tissue copper, metallothionein and glutathione reductase mRNA levels}

The levels of copper, MT and GR mRNA levels in the tissues of the fish used in this experiment have been reported in detail previously (Minghetti et al., 2008). Briefly, dietary excess copper increased copper levels in intestine and liver, after 30 days but not after 15, and not in gill at either time point. Waterborne excess copper increased copper levels in gill at 15 and 30 days and in liver after 15 days but not after 30, and not in intestine at either time point. Increases in tissue copper are indicated in Figure 6. Markers of toxicity, MT and GR mRNA, were increased in liver and gill after waterborne exposure but not after dietary exposure. 
Intestine

Gill

Kidney

Liver

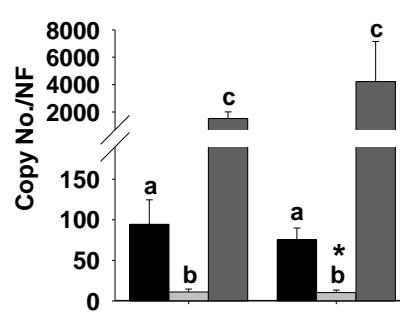

15
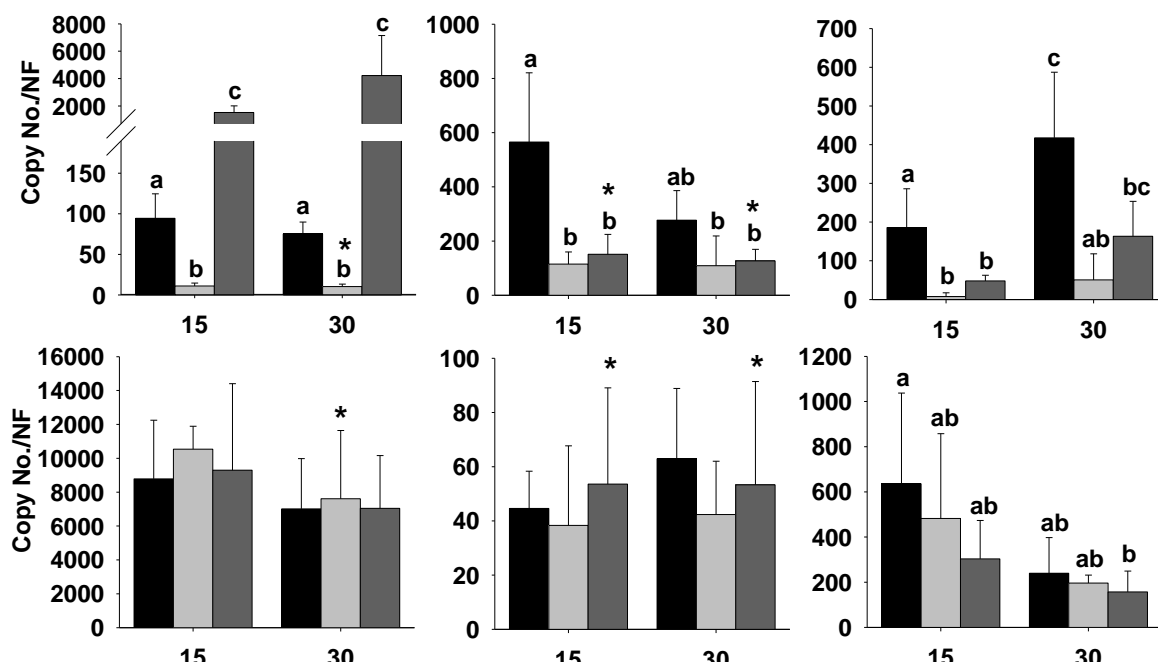

15
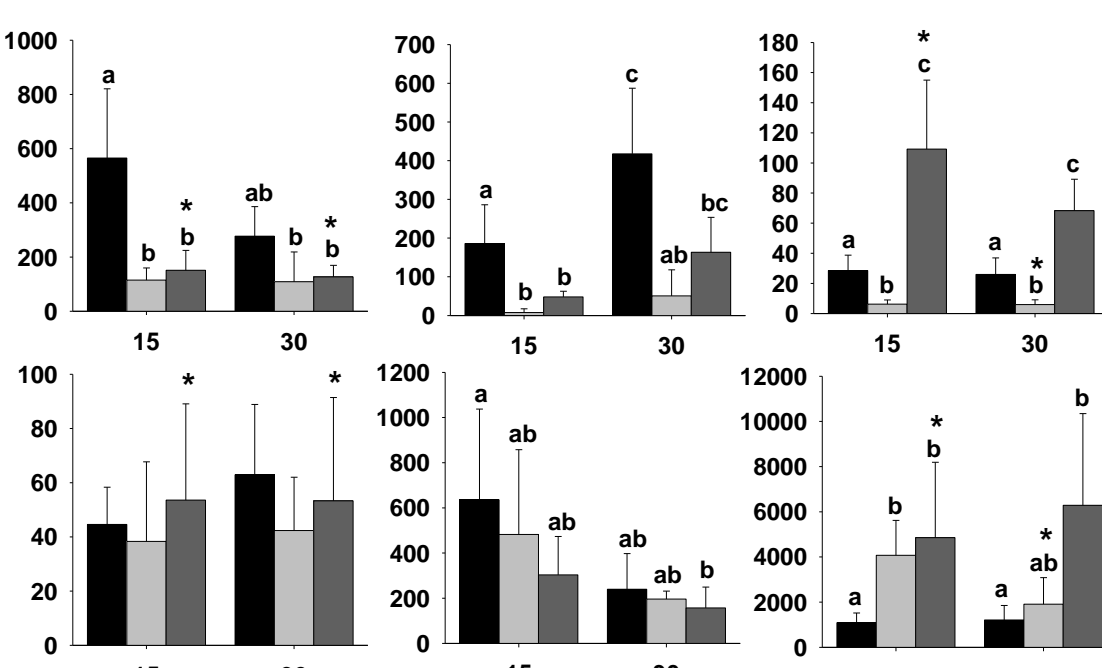

ATP7A
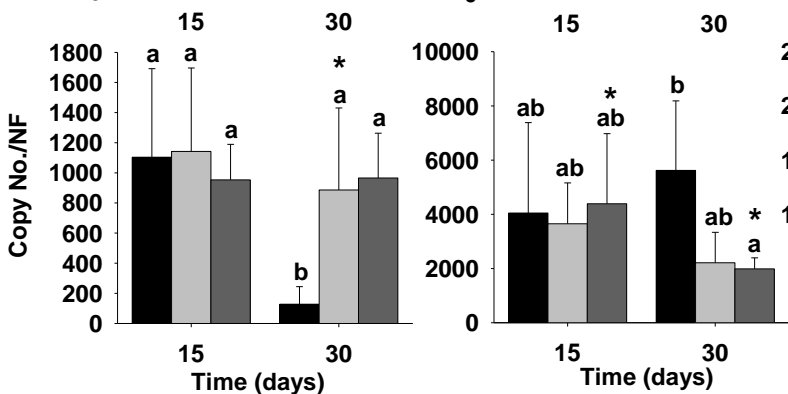

$\left.\begin{array}{r}25000 \\ 20000 \\ 15000 \\ 10000 \\ 5000 \\ 0\end{array}\right]$
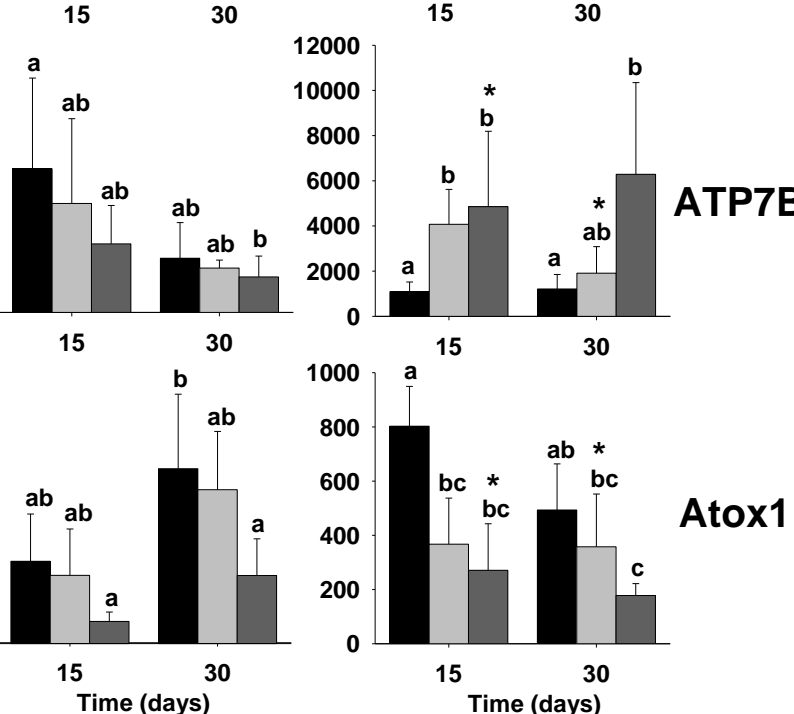

$\square$ Low Cu Diet $\square$ High Cu Diet $\square$ Low Cu Diet + Cu in water

Figure 6. ATP7A, ATP7B and Atox1 expression in sea bream tissues exposed to either dietary (high $\mathrm{Cu}$ diet; $130 \mathrm{mg} \mathrm{Kg}^{-1} \mathrm{Cu}$ ) or waterborne $\mathrm{Cu}$ (low $\mathrm{Cu}$ diet $+0.3 \mathrm{mg} \mathrm{L}^{-1} \mathrm{Cu}$ ). Copy numbers were normalized by geNorm using a normalization factor (NF) based on the geometric mean of $\beta$-actin, EF1 $\alpha$ or GAPDH reference genes. Values are means \pm S.D. $N=5$. Bars bearing different lettering are significantly different $(\mathrm{P}<0.05$; ANOVA, Tukeys test). Stars $(*)$ indicate tissue $\mathrm{Cu}$ accumulation (metal concentration not analysed in the kidney) (Minghetti et al., 2008).

\section{Discussion}

To enable a better understanding of $\mathrm{Cu}$ homeostasis in fish we have investigated the expression of genes coding for $\mathrm{Cu}$-transporters in the gilthead sea bream (Sparus aurata). We have shown for the first time in a lower vertebrate that homologues of the $\mathrm{Cu}$-ATPases, ATP7A and ATP7B and the chaperone responsible for delivering $\mathrm{Cu}$ to these proteins, ATOX1, are expressed. Moreover expression of mRNAs for these proteins is modulated by chronic $\mathrm{Cu}$ exposure, in a manner dependent on route of exposure.

\subsection{Evolutionary implications}

The $\mathrm{Cu}$-ATPases are key proteins in the delivery of $\mathrm{Cu}$ to cuproproteins and maintenance of $\mathrm{Cu}$ homeostasis, and homologues can be identified in all Phyla from yeast to man (Figure 1). Most notably, monocellular eukaryotes such as yeast (S. cerevisiae) and lower animals including arthropods (D. melanogaster, D. pulex), nematodes (C. elegans) and urochordates (C. intestinalis) 
have only one isoform of $\mathrm{Cu}$-ATPase whilst tetrapods possess two isoforms of $\mathrm{Cu}$-ATPases, ATP7A and ATP7B. Here we report for the first time ATP7A and ATP7B in teleosts, indicating that their evolutionary origins predate the divergence of lines leading to fish and mammals. In evolutionary history there have been a number of notable whole genome duplications (WGD), and following WGD, duplicated genes can be retained or lost in a lineage dependent manner while a small percentage of the duplicated genes may also undergo sub-functionalization or neofunctionalization to generate new phenotypes on which natural selection can act (Brunet et al., 2006). One of the most significant WGDs occurring in a vertebrate ancestor is hypothesized to have influenced vertebrate evolution and driven their evolutionary success (Dehal and Boore 2005). The $\mathrm{Cu}$-ATPases may provide an interesting example of a functional diversification of genes which were duplicated at the base of the vertebrate lineage. This diversification of function may reflect the dramatic differences in anatomy and physiology of vertebrates compared to invertebrates. Vertebrates have a closed circulatory system, an enterohepatic blood vessel and a hepato-biliary system, which when combined with the tissue specific expression and neo-functionalization of $\mathrm{Cu}$ ATPase genes and their products would enable a finer control of $\mathrm{Cu}$ homeostasis. Thus, in Drosophila, the single ATP7 has been shown to have a similar role to mammalian ATP7A in intestinal and cellular $\mathrm{Cu}$ absorption (Burke et al., 2008). However, Drosophila and other arthropods have different mechanisms of Cu excretion to mammals and the role of ATP7, if any is not clear. In fact Drosophila and other invertebrates seem to permanently accumulate $\mathrm{Cu}$ in insoluble granules and control $\mathrm{Cu}$ homeostasis mainly by regulating $\mathrm{Cu}$ absorption (Schofield et al., 1997; George and Viarengo 1985). In contrast, vertebrates excrete excess Cu through the hepatobiliary system and this is mediated by the activity of ATP7B; indeed this is known to be the main function of ATP7B in mammals (Lutsenko et al., 2007a). Therefore the duplication and subsequent neo-functionalization of $\mathrm{Cu}$-ATPases genes are an example of an evolutionary advance in $\mathrm{Cu}$ homeostasis facilitated by gene duplication as a result of WGD.

\subsection{Structure-function comparison}

In vertebrates, this neo-functionalisation of the duplicated $\mathrm{Cu}$-ATPase genes accompanying the development of closed circulatory, enterohepatic and hepato-biliary systems is reflected and facilitated by differences in their structures, which enables further control of function by regulation of trafficking of the proteins between different cellular membranes. During $\mathrm{Cu}$ transport ATP7A is targeted towards the basolateral membrane of polarized cells (Petris and Mercer 1999). In contrast, ATP7B is targeted to the apical membrane of polarized cells such as enterocytes and hepatocytes. This process is dependent on a motif which is present in ATP7B but not in ATP7A (Guo et al., 2005; Braiterman et al., 2009). These motifs are also conserved in chicken, frog and fish ATP7Bs 
(including saATP7B; Figure 1, Figure 2A) but not in other vertebrate ATP7As or in invertebrate $\mathrm{Cu}-\mathrm{ATPase}$ proteins.

Evolutionary elaboration of $\mathrm{Cu}$-homeostasis may also be evident from other structural distinctions between the $\mathrm{Cu}$-ATPase isoforms, notably by consideration of the number of metal binding domains (MBDs) in various Cu-ATPases enzymes. The role of the MBDs in both ATP7A and ATP7B has been investigated in several mammalian studies by structural (Banci et al., 2004; Achila et al., 2006; DiDonato et al., 2000) and functional (Mercer et al., 2003; Cater et al., 2004) approaches. Not all the MBDs have the same role. MBD5 and/or MBD6 coordinate $\mathrm{Cu}$ and deliver it to the CPC (cys-pro-cys) domain, located in the sixth trans-membrane domain, and is required for $\mathrm{Cu}$ transport across the membrane (Forbes and Cox 1998). The CPC domain is conserved in all the $\mathrm{Cu}$-ATPases, from yeast, through teleosts to mammals. In contrast MBD 1-4 in mammalian ATP7A and ATP7B seem to have a regulatory auto-inhibitory role as deletion of these domains increases hydrolysis of ATP suggesting an involvement in the regulation of catalytic turnover (Huster and Lutsenko 2003). Guo et al (2005) proposed that these MBDs sense the intracellular $\mathrm{Cu}$ concentration and regulate the activity of the protein accordingly. Thus, the number of MBDs in a $\mathrm{Cu}$-ATPase may 'fine-tune' $\mathrm{Cu}$ transport. In fish ATP7A has six MBDs, as in mammals, whilst the ATP7B's of the majority of fish including sea bream, Fugu, Medaka, Puffer and Stickleback only have four MBDs. . Thus, it is possible that the numbers of MBDs at the N-terminus of the protein have increased from yeast (2 MBDs) worm and fly (4MBDs), the sea squirt (5 MBDs), fish (6 MBDs in ATP7A and 4-5 in ATP7B) and then to mammals (6 MBDs in both ATP7A and ATP7B) under a selective pressure to acquire finer intracellular tuning of $\mathrm{Cu}$ homeostasis.

\subsection{Tissue expression profile}

In mammals further evidence for functional diversity of ATP7A and ATP7B is apparent from their differential tissue expression patterns. In adult animals very low levels of ATP7A are found in the liver, although it is ubiquitously expressed during development, whereas, ATP7B expression is more delimited and high levels of expression are only found in liver and intestine (Kuo et al., 1997). In sea bream the expression profiles of ATP7A and ATP7B are very similar to those in mammals (Figure 5). The distribution of ATP7A is reflective of its role in delivery of $\mathrm{Cu}$ to cuproenzymes eg. peptidyl- $\alpha$-monooxygenase (El Meskini et al., 2003), tyrosinase (Petris et al., 2000) and lysyl oxidase (Tchaparian et al., 2000). The high level of hepatic ATP7B expression in sea bream is in accord with its known functions in mammals, namely delivery of $\mathrm{Cu}$ to ceruloplasmin, a serum ferroxidase which mediates the release of iron from the liver and other tissues (Terada et al., 1998), and its role in the biliary excretion of $\mathrm{Cu}$. Biliary excretion is also the main excretory route for excess $\mathrm{Cu}$ in fish, renal excretion being minimal (Grosell et al., 1998). On the other hand, the high 
level of expression of ATP7B in the intestine, of both sea bream and mammals has not been satisfactorily explained, since it does not deliver $\mathrm{Cu}$ to ceruloplasmin in this tissue. Evidence from Menkes and Wilson diseases indicates that in tissues where ATP7A and ATP7B are co-expressed they have distinct non-overlapping roles since it has been demonstrated that one functionally active ATPase cannot compensate for lack of the other (Kuo et al., 1997; Linz and Lutsenko 2007; Barnes et al., 2005). Thus, even though ATP7B is functionally active in Menkes disease (ATP7A-deficient) patients, $\mathrm{Cu}$ still accumulates in the intestine. Possible intestinal roles have been suggested in $\mathrm{Cu}$ sequestration (Kaplan and Lutsenko 2009) or in the delivery of $\mathrm{Cu}$ to a serum carrier or another cupro-enzyme, such as the $\mathrm{Cu}$-dependent intra-membrane ferroxidase, hephaestin which has a functional role in intestinal iron transport (Wessling-Resnick 2006).

\subsection{Effects of copper exposure}

In this study, the effect of excess $\mathrm{Cu}$ on $\mathrm{Cu}$-ATPase mRNA expression during two alternative routes of exposure, diet and water, was measured. Copper absorption occurs primarily in the small intestine in mammals (Linder 1991) and in the mid posterior region of the gut in fish (Handy et al., 2000). The efficiency of $\mathrm{Cu}$ uptake has been demonstrated to be directly related to dietary $\mathrm{Cu}$ status; when $\mathrm{Cu}$ status is low, $\mathrm{Cu}$ absorption is enhanced, whilst when $\mathrm{Cu}$ status is high, $\mathrm{Cu}$ absorption is repressed (Turnlund 1998; Clearwater et al., 2000; Handy et al., 2000). However, the molecular mechanisms by which these physiological effects are mediated are unknown. Present evidence from mammals suggests that $\mathrm{Cu}$ absorption involves both passive diffusion at the intestinal brush border and active transport at the basolateral membrane, with the latter being the limiting step (Arredondo et al., 2000). The protein or mechanism responsible for apical Cu uptake is not clear (Zimnicka et al., 2007), although it has been suggested that low affinity transport of $\mathrm{Cu}^{1+}$ is mediated by the non-specific divalent metal ion transporter DMT-1 (Arredondo et al., 2003). Interestingly, when Caco-2 cells are exposed to high Cu levels, DMT1 protein and mRNA expression are markedly decreased (Tennant et al. 2002), similar to the response of ATP7 to excess copper in sea bream intestine shown here. At the basolateral membrane $\mathrm{Cu}$ transport from the enterocyte to the blood has been attributed to ATP7A (Voskoboinik and Camakaris 2002) while recent evidence suggest that blood-borne $\mathrm{Cu}$ is absorbed by the enterocyte through the high affinity transporter, CTR1 (Zimnicka et al., 2007) (Figure 7). Importantly in fish, there is physiological evidence for ATP-mediated basolateral membrane transport of $\mathrm{Cu}$ in both the gill (Bury et al., 1999; Campbell et al., 1999) and intestine (Bury et al., 2003; Handy et al., 2000). Since ATP7A but not ATP7B is expressed in both sea bream intestine and gill, ATP7A is implicated as the probable candidate for basolateral $\mathrm{Cu}$ transport in fish. 
In mammals, ATP7A function is thought to be regulated mainly at the post-translational level by alterations in membrane trafficking. Under acute conditions of elevated $\mathrm{Cu}$, it has been shown that there is a change in the subcellular localization of the protein from the trans golgi network to the cell periphery (Nyasae et al., 2007). However, in a chronic situation, suckling rats fed a diet containing moderate levels of $\mathrm{Cu}$ for 20 days, an increased mRNA level of ATP7A in intestine and ATP7B in the liver was observed (Bauerly et al 2004), inferring transcriptional regulation. In a recent study in zebrafish, Craig et al. (2009) reported an increased expression of intestinal and liver ATP7A mRNA after exposure to $8 \mu \mathrm{g} \mathrm{L}^{-1} \mathrm{Cu}$ in the water, a finding confirmed for a seawater fish in the present study. In both intestine and liver of sea bream (Minghetti et al., 2008) and zebrafish (Craig et al., 2009) expression of CTR1 mRNA is also increased by waterborne $\mathrm{Cu}$ exposure. In the present study, similar to suckling rats, we also observed induction of hepatic ATP7B expression in sea bream after $\mathrm{Cu}$ exposure. Thus, expression of the $\mathrm{Cu}$ transporters, CTR1, ATP7A and ATP7B might also be transcriptionally regulated by $\mathrm{Cu}$ exposure in fish.

Compared to fish fed the control low $\mathrm{Cu}$ diet, in fish fed the high $\mathrm{Cu}$ diet there was a reduction of ATP7A mRNA expression in all tissues analyzed after 30 days, which was most marked in intestine (9-fold). This was accompanied by a 50\% elevation in intestinal and liver Cu levels. Previous studies have demonstrated accumulation of $\mathrm{Cu}$ in intestine, liver and gill after feeding a diet containing 1500-2000 mg Cu Kg${ }^{-1}$ dry diet in African walking catfish (Clarias gariepinus) (Hoyle et al., 2007) and Nile tilapia (Oreochromis niloticus) (Shaw and Handy 2006). The accumulation of $\mathrm{Cu}$ in enterocytes may therefore be explained by a lack of ATP7A-dependent basolateral efflux of $\mathrm{Cu}$, caused by a decrease in ATP7A expression. In sea bream fed the high $\mathrm{Cu}$ diet accumulation of $\mathrm{Cu}$ occurred after 30 days in the liver and hepatic ATP7B mRNA expression was elevated by 3-fold after 15 days. Excess $\mathrm{Cu}$ is excreted via the bile in fish (Grosell et al., 1998) and biliary excretion is ATP7B-dependent in mammals (Schaefer et al., 1999). Our results together with increase in ATP7B mRNA reported in suckling rats fed elevated Cu (Bauerly et al., 2004) suggest that hepatic ATP7B may also be transcriptionally regulated in a chronic response to dietary $\mathrm{Cu}$-overload. The predicted consequence would be an increase in excreted biliary $\mathrm{Cu}$ complex and detoxification as such complexes are less easily reabsorbed in the gut (Linder et al., 1998).

The effects of waterborne $\mathrm{Cu}$ exposure on $\mathrm{Cu}$-transporter gene expression were significantly different from those observed under conditions of excess dietary $\mathrm{Cu}$-exposure and are more difficult to interpret since they show tissue dependent differences. It is well documented that fish can also absorb dissolved $\mathrm{Cu}$ from the water (Handy et al., 2002; Grosell and Wood 2002) and in trout exposed to $22 \mu \mathrm{g} \mathrm{Cu} \mathrm{L}^{-1}, \mathrm{Cu}$ appeared in the plasma within $3 \mathrm{~h}$ of exposure (Kamunde et al., 2002). High levels of waterborne $\mathrm{Cu}$ are highly toxic for fish, especially in fresh water (Lauren and McDonald 1985; Li et al., 1998) and although this is not generally a problem in marine fish due to 
the insolubility of $\mathrm{Cu}$ ions, it can become a problem due to anthropogenic activities (Morillo et al., 2005). ATP7B mRNA was expressed at negligible levels in the gill whilst ATP7A mRNA expression was reduced by 4 -fold by waterborne $\mathrm{Cu}$. $\mathrm{Cu}$ accumulated in the gills and liver and under these conditions both metallothionein and glutathione reductase are induced, reflective of an oxidative stress response due to $\mathrm{Cu}$ toxicity (Minghetti et al., 2008). Thus, any reductions in ATP7A activity resulting from reduced gill mRNA expression were not sufficient to prevent $\mathrm{Cu}$ entry to the body.

In intestine after waterborne exposure there was substantial 40-fold induction of ATP7A mRNA expression and there was no accumulation of $\mathrm{Cu}$ or an oxidative stress response. In addition, we previously reported a 3-fold induction of CTR1 under these conditions (Minghetti et al., 2008). These results indicate that the effects of $\mathrm{Cu}$ were unlikely to have been elicited through uptake of $\mathrm{Cu}$ by drinking, since this would involve exposure via the gut and would be expected to produce similar effects to dietary treatment. Induction of ATP7A and CTR1 mRNA's after exposure to waterborne $\mathrm{Cu}$ has also been reported in zebrafish intestine (Craig et al., 2009).

Based on the different effects of dietary and waterborne $\mathrm{Cu}$ on CTR1 expression in sea bream, we previously hypothesized that the form in which $\mathrm{Cu}$ is delivered to the liver and other tissues must differ in some way between intestinal- and gill-derived $\mathrm{Cu}$ (Minghetti et al., 2008). Our results show that the liver appears be able to cope with a high level of dietary $\mathrm{Cu}$ since $\mathrm{Cu}$ arriving from the intestine via the hepatic portal system does not induce biomarkers of toxicity (MT and GR) (Minghetti et al., 2008). Upon exposure to waterborne $\mathrm{Cu}$, the metal is presented to the liver from both hepatic portal and arterial blood and whilst we observed a modest induction of both hepatic ATP7A and ATP7B, toxicity was apparent from the oxidative stress responses of MT and GR. In mammals, $\mathrm{Cu}$ uptake is entirely from the diet via the intestine, after which it enters the hepatic portal vein and progresses to the liver where it mixes with arterial blood and is taken up by hepatocytes. The nature of the $\mathrm{Cu}$ carrier from the intestine is not clear, the main candidate is transcuprein, an $\alpha 2$-macroglobulin of 190-kDa (Liu et al., 2007). We contend that the difference in effect of $\mathrm{Cu}$ from gill uptake may be attributable to the nature of the plasma $\mathrm{Cu}$-complex, most probably as $\mathrm{Cu}$-histidine or $\mathrm{Cu}$-albumin (Lui et al., 2007), rather than a specific enterocyte-derived transporter. Thus the normal mode of entry may be bypassed, resulting in the observed induction of metal and oxidative stress after water borne exposure. This non-specific chelation of $\mathrm{Cu}$ after water borne exposure may also explain the unexpected "anti-homeostatic" response (increased CTR1 and ATP7A mRNA levels) we observed in the sea bream intestine (Minghetti et al., 2008) (Figure 6) and also reported in zebrafish (Craig et al., 2009). The increase in intestinal CTR1 and ATP7A mRNA may be induced by exposure to $\mathrm{Cu}$ present in the blood stream in a free or non-specifically bound form. Thus, this response could be part of a defense mechanism to increase the rate of 
intestinal $\mathrm{Cu}$ uptake and detoxification through incorporation into a specific $\mathrm{Cu}$ serum carrier, by ATP7A in the same way that dietary $\mathrm{Cu}$ is transported to liver. This mechanism would allow the delivery of $\mathrm{Cu}$ into the portal vein in a form that subsequently could be metabolized and excreted by the liver. Therefore the gut, like the liver, might be considered an organ of accumulation and detoxification.

The kidney is an organ which has a central role in body $\mathrm{Cu}$ homeostasis (Linder et al., 1998). In mammals, kidneys regulate their $\mathrm{Cu}$ content more efficiently than many other organs in pathologic conditions of $\mathrm{Cu}$ deficiency or excess by the action of ATP7A and ATP7B which are both required for normal function (Linz et al., 2007). In sea bream while renal ATP7A was reduced by waterborne $\mathrm{Cu}$, while under the same conditions $\mathrm{CTR} 1$ was increased by waterborne $\mathrm{Cu}$ (2.6-6 fold up) (Minghetti et al., 2008) . In fish, as in mammals, the normal role of the kidney is of $\mathrm{Cu}$ reabsorption since urinary excretion is negligible, but significantly $\mathrm{Cu}$ accumulates in this tissue after excess to excess (Grosell et al., 1997; Grosell et al., 2003). This might suggest that the kidney could function as an organ of $\mathrm{Cu}$ defense through accumulation in conditions of excess $\mathrm{Cu}$.

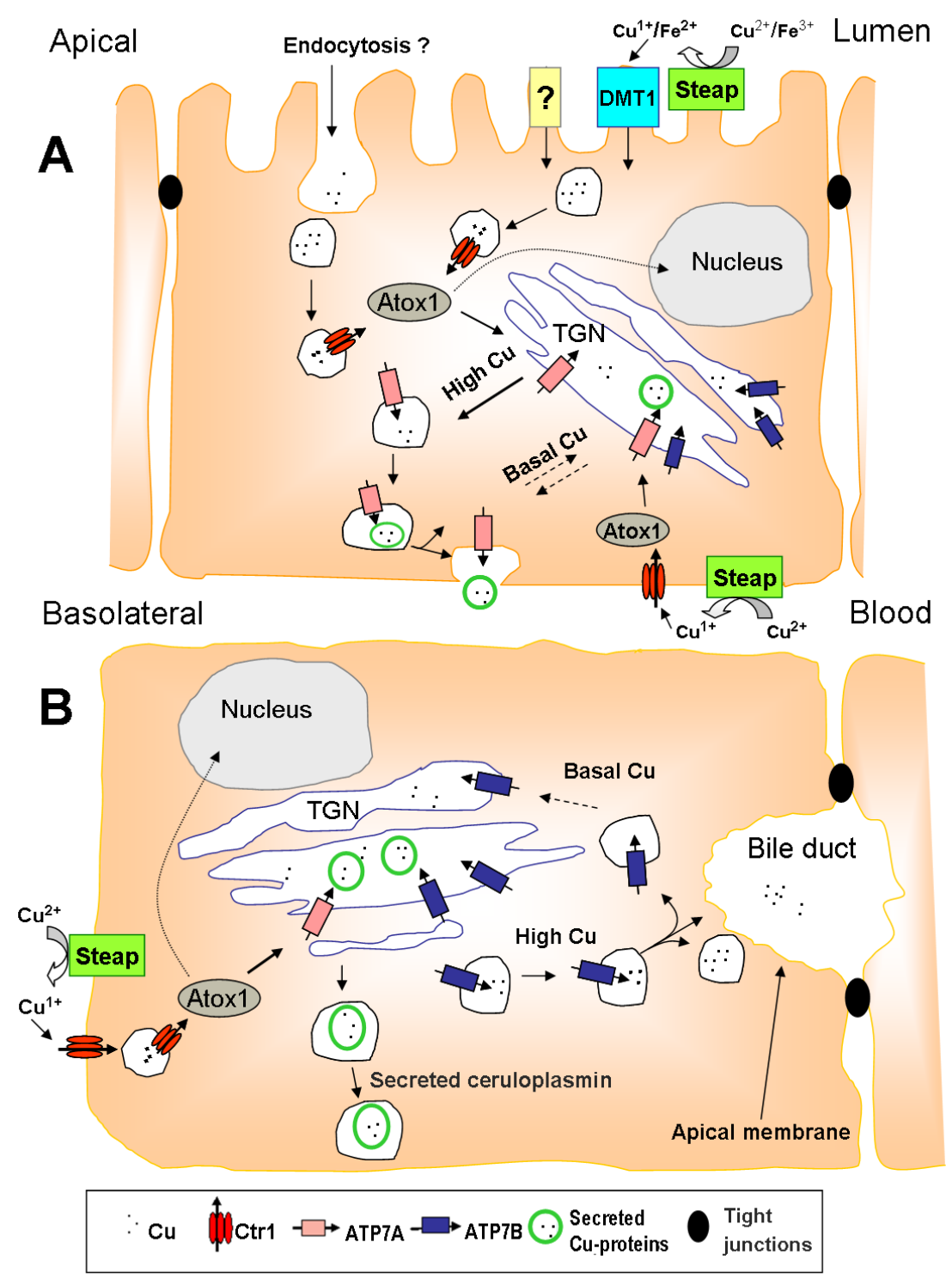


Figure 7. Proposed model of copper transporters trafficking and their intracellular localization in enterocytes (A) and hepatocytes (B). Copper enters via CTR1 at the basolateral membrane in all cells or via DMT1, endocytosis or other unidentified transporters at the apical membrane in enterocytes. Previous entry via $\mathrm{CTR} 1$ and DMT1 $\mathrm{Cu}$ is reduced by the metalloreductase Steap. After entry $\mathrm{Cu}$ is bound to the chaperone ATOX1 which has recently been shown to act as a transcription factor together with its initially identified function to deliver $\mathrm{Cu}$ to the $\mathrm{Cu}$-ATPases located at the TGN. ATP7A and ATP7B may then deliver $\mathrm{Cu}$ to cupro-enzymes and secretory $\mathrm{Cu}$-proteins. Under basal $\mathrm{Cu}$ condition (dotted arrows), ATP7A cycles between the TGN and the basolateral membrane in enterocytes while ATP7B is located at the TGN. When intracellular copper levels increase (solid arrows), in the enterocyte, ATP7A is sorted into vesicles that move toward the basolateral membrane and $\mathrm{Cu}$-loaded vesicles may fuse with the membrane to release copper incorporated into secretory proteins by exocytosis. Conversely with elevated $\mathrm{Cu}$, in the hepatocyte, ATP7B sequester $\mathrm{Cu}$ into vesicles that move toward the apical membrane (or canalicular membrane) where vesicles may fuse with this membrane and release $\mathrm{Cu}$, empty vesicles containing ATP7B would then be recycled trafficking back to the TGN (Adapted from La Fontaine and Mercer, (2007)).

\subsection{Conclusions}

In summary, in this study we report for the first time that fish possess two isoforms of Cu-ATPases which are homologues of the human ATP7A and ATP7B, and structural consideration together with basal tissue expression levels suggest similar functional roles in teleosts and tetrapods. Phylogenetic analysis of diverse $\mathrm{Cu}$-ATPases suggest that the two vertebrate genes arose and neo-functionalized from a single ancestral gene at a similar time to the evolutionary appearance of a closed blood circulation, an enterohepatic blood vessel and a hepato-biliary system. The expression of sea bream $\mathrm{Cu}$-ATPase (saATP7A and saATP7B) mRNAs are consistent with the available physiological evidence from various fish species for the involvement of ATP dependent (ATP7A-B-like) Cu transporters under conditions of both normal and excess $\mathrm{Cu}$ exposure. The alterations in expression of these genes, when fish are exposed chronically to excesses of dietary or waterborne $\mathrm{Cu}$, show that they may under $\mathrm{Cu}$-dependent transcriptional regulation and that the route of exposure is critical to maintenance of $\mathrm{Cu}$ homeostasis and the manifestation of toxic effects.

\section{ACKNOWLEDGMENTS}

We thank Adam Southon and Dr. Fanis Missirlis for helpful comments on this manuscript.

\section{References}

Achila, D., Banci, L., Bertini, I., Bunce, J., Ciofi-Baffoni, S., and Huffman, D. L. 2006, Structure of human Wilson protein domains 5 and 6 and their interplay with domain 4 and the copper chaperone HAH1 in copper uptake, Proceedings of the National Academy of Sciences, vol. 103, no. 15 , pp. $5729-5734$.

Arredondo, M., Munoz, P., Mura, C. V., and Nunez, M. T. 2003, DMT1, a physiologically relevant apical Cu1+ transporter of intestinal cells, AJP - Cell Physiology, vol. 284, no. 6, p. C1525C1530. 
Arredondo, M., Uauy, R., and Gonzalez, M. 2000, Regulation of copper uptake and transport in intestinal cell monolayers by acute and chronic copper exposure, Biochimica et Biophysica Acta (BBA) - General Subjects, vol. 1474, no. 2, pp. 169-176.

Banci, L., Bertini, I., DelConte, R., D'Onofrio, M., and Rosato, A. 2004, Solution Structure and Backbone Dynamics of the $\mathrm{Cu}(\mathrm{I})$ and Apo Forms of the Second Metal-Binding Domain of the Menkes Protein ATP7A, Biochemistry, vol. 43, no. 12, pp. 3396-3403.

Barnes, N., Tsivkovskii, R., Tsivkovskaia, N., and Lutsenko, S. 2005, The Copper-transporting ATPases, Menkes and Wilson Disease Proteins, Have Distinct Roles in Adult and Developing Cerebellum, Journal of Biological Chemistry, vol. 280, no. 10, pp. 9640-9645.

Bauerly, K. A., Kelleher, S. L., and Lonnerdal, B. 2004, Functional and molecular responses of suckling rat pups and human intestinal Caco-2 cells to copper treatment, The Journal of Nutritional Biochemistry, vol. 15, no. 3, pp. 155-162.

Braiterman, L., Nyasae, L., Guo, Y., Bustos, R., Lutsenko, S., and Hubbard, A. 2009, Apical targeting and Golgi retention signals reside within a 9-amino acid sequence in the copperATPase, ATP7B, AJP - Gastrointestinal and Liver Physiology, vol. 296, no. 2, p. G433-G444.

Brunet, F. G., Crollius, H. R., Paris, M., Aury, J. M., Gibert, P., Jaillon, O., Laudet, V., and Robinson-Rechavi, M. 2006, Gene Loss and Evolutionary Rates Following Whole-Genome Duplication in Teleost Fishes, Molecular Biology and Evolution, vol. 23, no. 9, pp. 1808-1816.

Burke, R., Commons, E., and Camakaris, J. 2008, Expression and localisation of the essential copper transporter DmATP7 in Drosophila neuronal and intestinal tissues, The International Journal of Biochemistry \& Cell Biology, vol. 40, no. 9, pp. 1850-1860.

Bury, N. R., Grosell, M., Grover, A. K., and Wood, C. M. 1999, ATP-dependent silver transport across the basolateral membrane of rainbow trout gills., Toxicology and applied pharmacology, vol. 159 , no. 1 , pp. 1-8.

Bury, N. R., Walker, P. A., and Glover, C. N. 2003, Nutritive metal uptake in teleost fish, Journal of Experimental Biology, vol. 206, no. 1, pp. 11-23.

Campbell, H. A., Handy, R. D., and Nimmo, M. 1999, Copper uptake kinetics across the gills of rainbow trout (Oncorhynchus mykiss) measured using an improved isolated perfused head technique, Aquatic Toxicology, vol. 46, pp. 177-190.

Cater, M. A., Forbes, J., La Fontaine, S., Cox, D., and Mercer, J. F. B. 2004, Intracellular trafficking of the human Wilson protein: the role of the six N-terminal metal-binding sites, Biochemical Journal, vol. 380, no. 3, pp. 805-813.

Clearwater, S. J., Baskin, S. J., Wood, C. M., and McDonald, D. G. 2000, Gastrointestinal uptake and distribution of copper in rainbow trout, Journal of Experimental Biology, vol. 203, no. 16, pp. 2455-2466. 
Craig, P. M., Galus, M., Wood, C. M., and McClelland, G. B. 2009, Dietary iron alters waterborne copper-induced gene expression in soft water acclimated zebrafish (Danio rerio), AJP Regulatory, Integrative and Comparative Physiology, vol. 296, no. 2, p. R362-R373.

Dehal, P. and Boore, J. L. 2005, Two Rounds of Whole Genome Duplication in the Ancestral Vertebrate, PLoS Biology, vol. 3, no. 10, p. e314.

DiDonato, M., Hsu, H. F., Narindrasorasak, S., Que, L., and Sarkar, B. 2000, Copper-Induced Conformational Changes in the N-Terminal Domain of the Wilson Disease Copper-Transporting ATPase, Biochemistry, vol. 39, no. 7, pp. 1890-1896.

El Meskini, R., Culotta, V. C., Mains, R. E., and Eipper, B. A. 2003, Supplying Copper to the Cuproenzyme Peptidylglycine alpha -Amidating Monooxygenase, Journal of Biological Chemistry, vol. 278, no. 14, pp. 12278-12284.

Forbes, J. R. and Cox, D. W. 1998, Functional Characterization of Missense Mutations in ATP7B: Wilson Disease Mutation or Normal Variant?, The American Journal of Human Genetics, vol. 63, no. 6, pp. 1663-1674.

George, S. G. \& Viarengo, A. 1985, "A model for heavy metal homeostasis and detoxification," in Marine Pollution and Physiology: Recent Advances, W. Vernberg et al., eds., University of South Carolina Press, Columbia, pp. 125-143.

Grosell, M., Hogstrand, C., and Wood, C. M. 1998, Renal $\mathrm{Cu}$ and $\mathrm{Na}$ excretion and hepatic $\mathrm{Cu}$ metabolism in both $\mathrm{Cu}$ acclimated and non acclimated rainbow trout (Oncorhynchus mykiss), Aquatic Toxicology, vol. 40, pp. 275-291.

Grosell, M., Hogstrand, C., and Wood, C. M. 1997, Cu uptake and turnover in both Cu-acclimated and non-acclimated rainbow trout (Oncorhynchus mykiss)., Aquatic Toxicology, vol. 38, pp. 257-276.

Grosell, M., Wood, C. M., and Walsh, P. J. 2003, Copper homeostasis and toxicity in the elasmobranch Raja erinacea and the teleost Myoxocephalus octodecemspinosus during exposure to elevated water-borne copper., Comparative biochemistry and physiology.Toxicology \& pharmacology : CBP, vol. 135, pp. 179-190.

Grosell, M. and Wood, C. M. 2002, Copper uptake across rainbow trout gills: mechanisms of apical entry, Journal of Experimental Biology, vol. 205, no. 8, pp. 1179-1188.

Guo, Y., Nyasae, L., Braiterman, L. T., and Hubbard, A. L. 2005, NH2-terminal signals in ATP7B $\mathrm{Cu}$-ATPase mediate its $\mathrm{Cu}$-dependent anterograde traffic in polarized hepatic cells, AJP Gastrointestinal and Liver Physiology, vol. 289, no. 5, p. G904-G916.

Halliwell, B. and Gutteridge, J. M. 1984, Free radicals, lipid peroxidation and cell damage, Lancet, vol. 2, no. 8411, p. 1095.

Hamza, I., Prohaska, J., and Gitlin, J. D. 2003, Essential role for Atox 1 in the copper-mediated intracellular trafficking of the Menkes ATPase, Proceedings of the National Academy of Sciences, vol. 100 , no. 3, pp. 1215-1220. 
Handy, R. D., Eddy, F. B., and Baines, H. 2002, Sodium-dependent copper uptake across epithelia: a review of rationale with experimental evidence from gill and intestine., Biochimica et Biophysica Acta (BBA), vol. 1566, no. 1-2, pp. 104-115.

Handy, R. D., Musonda, M. M., Phillips, C., and Falla, S. J. 2000, Mechanisms of gastrointestinal copper absorption in the African walking catfish: copper dose-effects and a novel aniondependent pathway in the intestine, Journal of Experimental Biology, vol. 203, no. 15, pp. 23652377.

Hoyle, I., Shaw, B. J., and Handy, R. D. 2007, Dietary copper exposure in the African walking catfish, Clarias gariepinus: Transient osmoregulatory disturbances and oxidative stress, Aquatic Toxicology, vol. 83, no. 1, pp. 62-72.

Hung, I. H., Casareno, R. L., Labesse, G., Mathews, F. S., and Gitlin, J. D. 1998, HAH1 Is a Copper-binding Protein with Distinct Amino Acid Residues Mediating Copper Homeostasis and Antioxidant Defense, Journal of Biological Chemistry, vol. 273, no. 3, pp. 1749-1754.

Huster, D. and Lutsenko, S. 2003, The Distinct Roles of the N-terminal Copper-binding Sites in Regulation of Catalytic Activity of the Wilson's Disease Protein, Journal of Biological Chemistry, vol. 278, no. 34, pp. 32212-32218.

Itoh, S., Kim, H. W., Nakagawa, O., Ozumi, K., Lessner, S. M., Aoki, H., Akram, K., McKinney, R. D., Ushio-Fukai, M., and Fukai, T. 2008, Novel Role of Antioxidant-1 (Atox1) as a Copperdependent Transcription Factor Involved in Cell Proliferation, Journal of Biological Chemistry, vol. 283, no. 14, pp. 9157-9167.

Kamunde, C., Clayton, C., and Wood, C. M. 2002, Waterborne vs. dietary copper uptake in rainbow trout and the effects of previous waterborne copper exposure, AJP - Regulatory, Integrative and Comparative Physiology, vol. 283, no. 1, p. R69-R78.

Kaplan, J. H. and Lutsenko, S. 2009, Copper transport in mammalian cells: Special care for a metal with special needs, Journal of Biological Chemistry p. R109.

Kim, B. E., Nevitt, T., and Thiele, D. J. 2008, Mechanisms for copper acquisition, distribution and regulation, Nat Chem Biol, vol. 4, no. 3, pp. 176-185.

Kuo, Y. M., Gitschier, J., and Packman, S. 1997, Developmental expression of the mouse mottled and toxic milk genes suggests distinct functions for the Menkes and Wilson disease copper transporters, Human Molecular Genetics, vol. 6, no. 7, pp. 1043-1049.

Lauren, D. J. and McDonald, D. G. 1985, Effects of copper on branchial ionregulationin the rainbow trout, Salmo gairdnei Richardson- modulation by water hardness and $\mathrm{pH}$., Journal of Comparative Phisilogy, vol. 155, pp. 635-644.

La Fontaine, S. and Mercer, J. F. B. 2007, Trafficking of the copper-ATPases, ATP7A and ATP7B: Role in copper homeostasis, Archives of biochemistry and biophysics, vol. 463, no. 2, pp. 149167. 
Li, J., Quabius, E. S., Wendelaar Bonga, S. E., Flik, G., and Lock, R. A. C. 1998, Effects of waterborne copper on branchial chloride cells and $\mathrm{Na}+/ \mathrm{K}+$-ATPase activities in Mozambique tilapia (Oreochromis mossambicus), Aquatic Toxicology, vol. 43, no. 1, pp. 1-11.

Linder, M. C. 1991, Biochemistry of Copper New York.

Linder, M. C., Wooten, L., Cerveza, P., Cotton, S., Shulze, R., and Lomeli, N. 1998, Copper transport, American Journal of Clinical Nutrition, vol. 67(suppl), no. 5 suppl, pp. 965S-971S.

Linz, R. and Lutsenko, S. 2007, Copper-transporting ATPases ATP7A and ATP7B: cousins, not twins, Journal of bioenergetics and biomembranes.

Lui, N., Lo, L. S., Askary, S. H., Jones, L., Kidane, T. Z., Trang, T., Nguyen, M., Goforth, J., Chu, Y. H., Vivas, E., Tsai, M., Westbrook, T., and Linder, M. C. 2007, Transcuprein is a macroglobulin regulated by copper and iron availability., Journal of Nutritional Biochemistry, vol. 18 , no. 9 , pp. 597-608.

Lutsenko, S., Barnes, N. L., Bartee, M. Y., and Dmitriev, O. Y. 2007a, Function and Regulation of Human Copper-Transporting ATPases, Physiological Reviews, vol. 87, no. 3, pp. 1011-1046.

Lutsenko, S., Gupta, A., Burkhead, J. L., and Zuzel, V. 2008, Cellular multitasking: The dual role of human $\mathrm{Cu}$-ATPases in cofactor delivery and intracellular copper balance, Archives of biochemistry and biophysics, vol. 476, no. 1, pp. 22-32.

Lutsenko, S., LeShane, E. S., and Shinde, U. 2007b, Biochemical basis of regulation of human copper-transporting ATPases, Archives of biochemistry and biophysics, vol. 463, no. 2, pp. 134148.

Mendelsohn, B. A., Yin, C., Johnson, S. L., Wilm, T. P., Solnica-Krezel, L., and Gitlin, J. D. 2006, Atp7a determines a hierarchy of copper metabolism essential for notochord development., Cell metabolism, vol. 4, no. 2, pp. 155-162.

Mercer, J. F. 2001, The molecular basis of copper-transport diseases., Trends in molecular medicine, vol. 7, no. 2, pp. 64-69.

Mercer, J. F. B., Barnes, N., Stevenson, J., Strausak, D., and Llanos, R. M. 2003, Copper-induced trafficking of the $\mathrm{Cu}$-ATPases: A key mechanism for copper homeostasis, BioMetals, vol. 16, no. 1 , pp. $175-184$.

Minghetti, M., Leaver, M. J., Carpenè, E., and George, S. G. 2008, Copper transporter 1, metallothionein and glutathione reductase genes are differentially expressed in tissues of sea bream (Sparus aurata) after exposure to dietary or waterborne copper, Comparative Biochemistry and Physiology Part C: Toxicology \& Pharmacology, vol. 147, no. 4, pp. 450-459.

Morillo, J., Usero, J., and Gracia, I. 2005, Biomonitoring of trace metals in a mine-polluted estuarine system (Spain), Chemosphere, vol. 58, no. 10, pp. 1421-1430. 
Norgate, M., Lee, E., Southon, A., Farlow, A., Batterham, P., Camakaris, J., and Burke, R. 2006, Essential Roles in Development and Pigmentation for the Drosophila Copper Transporter DmATP7, Molecular Biology of the Cell, vol. 17, no. 1, pp. 475-484.

Nyasae, L., Bustos, R., Braiterman, L., Eipper, B., and Hubbard, A. 2007, Dynamics of endogenous ATP7A (Menkes protein) in intestinal epithelial cells: copper-dependent redistribution between two intracellular sites, AJP - Gastrointestinal and Liver Physiology, vol. 292, no. 4, p. G1181G1194.

Petris, M. J. and Mercer, J. F. 1999, The menkes protein (ATP7A; MNK) cycles via the plasma membrane both in basal and elevated extracellular copper using a C-terminal di-leucine endocytic signal, Human Molecular Genetics, vol. 8, no. 11, pp. 2107-2115.

Petris, M. J., Strausak, D., and Mercer, J. F. B. 2000, The Menkes copper transporter is required for the activation of tyrosinase, Human Molecular Genetics, vol. 9, no. 19, pp. 2845-2851.

Portnoy, M. E., Schmidt, P. J., Rogers, R. S., and Culotta, V. C. 2001, Metal transporters that contribute copper to metallochaperones in Saccharomyces cerevisiae, Molecular Genetics and Genomics, vol. 265, no. 5, pp. 873-882.

Predki, P. F. and Sarkar, B. 1992, Effect of replacement of "zinc finger" zinc on estrogen receptor DNA interactions, Journal of Biological Chemistry, vol. 267, no. 9, pp. 5842-5846.

Saitou, N. and Nei, M. 1987, The neighbor-joining method: a new method for reconstructing phylogenetic trees, Molecular Biology and Evolution, vol. 4, no. 4, pp. 406-425.

Schaefer, M., Hopkins, R. G., Failla, M. L., and Gitlin, J. D. 1999, Hepatocyte-specific localization and copper-dependent trafficking of the Wilson's disease protein in the liver, AJP Gastrointestinal and Liver Physiology, vol. 276, no. 3, p. G639-G646.

Schofield, R. M., Postlethwait, J. H., and Lefevre, H. W. 1997, MeV-ion microprobe analyses of whole Drosophila suggest that zinc and copper accumulation is regulated storage not deposit excretion, Journal of Experimental Biology, vol. 200, no. 24, pp. 3235-3243.

Shaw, B. J. and Handy, R. D. 2006, Dietary copper exposure and recovery in Nile tilapia, Oreochromis niloticus, Aquatic Toxicology, vol. 76, no. 2, pp. 111-121.

Tamura, K., Dudley, J., Nei, M., and Kumar, S. 2007, MEGA4: Molecular Evolutionary Genetics Analysis (MEGA) Software Version 4.0, Molecular Biology and Evolution, vol. 24, no. 8, pp. 1596-1599.

Tchaparian, E. H., Uriu-Adams, J. Y., Keen, C. L., Mitchell, A. E., and Rucker, R. B. 2000, Lysyl Oxidase and P-ATPase-7A Expression during Embryonic Development in the Rat, Archives of biochemistry and biophysics, vol. 379, no. 1, pp. 71-77.

Tennant, J., Stansfield, M., Yamaji, S., Srai, S.K. and Sharp, P. 2002, Effects of copper on the expression of metal transporters in human intestinal Caco-2 cells. FEBS Letters 527, 239-244. 
Terada, K., Nakako, T., Yang, X. L., Iida, M., Aiba, N., Minamiya, Y., Nakai, M., Sakaki, T., Miura, N., and Sugiyama, T. 1998, Restoration of Holoceruloplasmin Synthesis in LEC Rat after Infusion of Recombinant Adenovirus Bearing WND cDNA, Journal of Biological Chemistry, vol. 273, no. 3, pp. 1815-1820.

Thompson, J. D., Plewniak, F., Thierry, J. C., and Poch, O. 2000, DbClustal: rapid and reliable global multiple alignments of protein sequences detected by database searches, Nucleic Acids Research, vol. 28, no. 15, pp. 2919-2926.

Turnlund, J. R. 1998, Human whole-body copper metabolism, American Journal of Clinical Nutrition, vol. 67, no. 5, pp. 960S-9964.

Vandesompele, J., De Preter, K., Pattyn, F., Poppe, B., Van Roy, N., De Paepe, A., and Speleman, F. 2002, Accurate normalization of real-time quantitative RT-PCR data by geometric averaging of multiple internal control genes, Genome Biology, vol. 3, no. 7, p. research0034.

Voskoboinik, I. and Camakaris, J. 2002, Menkes copper-translocating P-type ATPase (ATP7A): biochemical and cell biology properties, and role in Menkes disease., Journal of bioenergetics and biomembranes, vol. 34, no. 5, pp. 363-371.

Wernimont, A. K., Huffman, D. L., Lamb, A. L., O'Halloran, T. V., and Rosenzweig, A. C. 2000, Structural basis for copper transfer by the metallochaperone for the Menkes/Wilson disease proteins, Nat Struct Mol Biol, vol. 7, no. 9, pp. 766-771.

Wessling-Resnick, M. 2006, Iron Imports. III. Transfer of iron from the mucosa into circulation, AJP - Gastrointestinal and Liver Physiology, vol. 290, no. 1, p. G1-G6.

Zar, J. H. 1999, "Biostatistical Analysis," forth edn, Prentice-Hall International, New Jersey, p. 663.

Zimnicka, A. M., Maryon, E. B., and Kaplan, J. H. 2007, Human Copper Transporter hCTR1 Mediates Basolateral Uptake of Copper into Enterocytes: Implications for copper homeostasis, Journal of Biological Chemistry, vol. 282, no. 36, pp. 26471-26480. 